IZA DP No. 7074

Labour Turnover and the Spatial Distribution of Unemployment: A Panel Data Analysis Using Employment Registry Data

Francesco Pastore

Joanna Tyrowicz

December 2012 


\title{
Labour Turnover and the Spatial Distribution of Unemployment: A Panel Data Analysis Using Employment Registry Data
}

\author{
Francesco Pastore \\ Seconda Università di Napoli \\ and IZA \\ Joanna Tyrowicz \\ University of Warsaw, \\ National Bank of Poland and RCEA
}

Discussion Paper No. 7074 December 2012

\author{
IZA \\ P.O. Box 7240 \\ 53072 Bonn \\ Germany \\ Phone: +49-228-3894-0 \\ Fax: +49-228-3894-180 \\ E-mail: iza@iza.org
}

Any opinions expressed here are those of the author(s) and not those of IZA. Research published in this series may include views on policy, but the institute itself takes no institutional policy positions. The IZA research network is committed to the IZA Guiding Principles of Research Integrity.

The Institute for the Study of Labor (IZA) in Bonn is a local and virtual international research center and a place of communication between science, politics and business. IZA is an independent nonprofit organization supported by Deutsche Post Foundation. The center is associated with the University of Bonn and offers a stimulating research environment through its international network, workshops and conferences, data service, project support, research visits and doctoral program. IZA engages in (i) original and internationally competitive research in all fields of labor economics, (ii) development of policy concepts, and (iii) dissemination of research results and concepts to the interested public.

IZA Discussion Papers often represent preliminary work and are circulated to encourage discussion. Citation of such a paper should account for its provisional character. A revised version may be available directly from the author. 


\section{ABSTRACT}

\section{Labour Turnover and the Spatial Distribution of Unemployment: A Panel Data Analysis Using Employment Registry Data}

This paper aims to study whether the local variation in unemployment rates is related to labour turnover and what is the sign of such relationship. In addition, the paper aims to assess the relative impact of inflow and outflow from unemployment on the dynamics of the local unemployment rate. The empirical analysis is based on a newly available unique dataset from the employment registry of a transition economy (Poland), encompassing nine years of monthly data (from 2000 to 2008) at a county (poviat) level. We find that turnover, as well as inflows and outflows separately, are ceteris paribus positively related to the unemployment level. This general conclusion is robust to sub-sampling that addresses potential heterogeneity of the analysed local labour markets. It is also robust to the use of different panel estimators as well as for spatial clustering of poviats. We also find that elasticity is larger in the case of the inflow rate than for the outflow rate. Finally, we demonstrate that the effect is stronger in low unemployment regions.

JEL Classification: C33, J63, P25, P52, R23

Keywords: regional unemployment, labour turnover, panel data, Poland

Corresponding author:

Francesco Pastore

Seconda Università di Napoli

Faculty of Law

Via Mazzocchi, 5

81055 Santa Maria Capua Vetere (CE)

Italy

E-mail: francesco.pastore@unina2.it 


\section{Introduction}

Based on theoretical reasoning (Aghion and Blanchard, 1994), the relationship between labour market turnover and the unemployment rate can be of different nature. There could be either a positive relationship or no relationship. Intuitively, in the latter case, high unemployment regions have an insufficient ability to create new jobs. In the former case, large turnover is an indication of a continuous high rate of layoff and hiring, thus leading to a (possibly temporary) unemployment increase. In turn, industrial restructuring causing sectoral shifts could explain the high degree of turnover of high unemployment regions (so-called Lilien hypothesis). Alternatively, large labour market flows might be the sign of greater labour market flexibility, which is usually associated with efficient labour markets and thus relatively lower unemployment (so-called Krugman hypothesis).

The aim of this paper is to empirically discriminate between these alternative theoretical hypotheses by exploiting the geographical differentiation of labour turnover and unemployment. Ferragina and Pastore (2008) suggest that in fact this test constitutes a "screening device" to distinguish the case when unemployment is due also to some region-specific shock (namely the high degree of labour turnover in high unemployment regions caused by industrial restructuring) and when it is due instead solely to labour market rigidities. Note that the policy implications of these alternative hypotheses are partly different, because a low job finding rate in high unemployment regions essentially indicates the need for supply side policies, whereas a positive relationship between labour market turnover and unemployment necessitates interventions on the demand side as well.

We use local level data encompassing nearly ten years of monthly observations (from 2000 to 2008) relative to 380 poviats (i.e. counties classified in the EU as LAU1 units) of a transition economy (Poland). To our knowledge, few other countries have similar data, which makes this study the first one to implement a systematic analysis of the relationship between the geographical pattern of unemployment and that of the labour market dynamics. The length of the period that the data covers allows us to consider both times of considerable unemployment growth (20012003) and of subsequent decrease (2005 onwards).

The estimates provide evidence of a positive coefficient on turnover, much larger for the inflow than for the outflow. Estimations are robust to the inclusion of a number of control variables, several stratifications and different types of estimation techniques. To adequately tackle the dynamic component of the data, we employ both fixed effect GLS panel data estimation with time controls and the alternative specifications of GMM.

In addition, the paper attempts to disentangle market driven from administrative flows, on the ground that the former might be correlated to structural change and the latter to institutional features of the labour market. The former flow includes those who register for the first time and those who find a job, whereas the latter also includes the re-registrations and those who are de-listed because of administrative reasons or because they are attending labour market programmes.

Furthermore, to verify the robustness of the results we also isolate the poviats where industrial restructuring has been more intense. We introduce a classification based on the share of private employment, employment in services and of investment. We end up with three different clusters of poviats: a) "laggards" are the poviats included in the bottom 25th percentiles of the distribution of the aforementioned variables; b) "in transition" are intermediate cases of poviats with a high employment share of both the rural and service industry; while c) "privatized industrial" are those with high private ownership and high industry contribution. We find that that the correlation between labour turnover and unemployment is universal across the clusters, but quantitatively the strongest in the most industrialized clusters of poviats. 
As a final check, the estimates are run for poviats at different deciles of the unemployment distribution. The estimates show that the elasticity of unemployment to labour turnover, inflow and outflow rates, which is positive in all groups of poviats, is much higher than average in low unemployment poviats, where the rate of structural change is supposedly greater.

The paper is structured as follows. In the next section motivation is briefly discussed, with some insights into the interplay between geography and unemployment in transition economies. Section 2 discusses the relevant theoretical foundations in detail as well as some available empirical evidence. Subsequently, we describe the dataset (Section 3) and the methodology (Section 4). Section 5 presents the analysis of the results. Concluding remarks and emerging policy implications are included in the final section.

\section{A survey of the literature}

Before presenting the data and econometric methodology, this section defines the main hypotheses to test. The first section focuses on the link between local worker reallocation and unemployment, and shows that different a priori relationships might possibly exist among them and brings to the fore three alternative hypotheses to test. The section also summarises the main empirical contributions that support each hypothesis. The ensuing section argues that the empirical literature has attempted to disentangle three possible sources of differences in labour reallocation across regions, namely sectoral shifts, aggregate disturbances and job-to-job moves. The last section discusses the main findings of the literature on Poland.

\subsection{The link between local worker reallocation and unemployment}

The Aghion and Blanchard (1994) model can be used as a framework to study the way how labour market dynamics affects the regional distribution of unemployment. Assume that the hiring rate is a bell-shaped function of unemployment. This non-linearity depends on the double effect of unemployment on hiring: on the one hand, unemployment reduces wages, and therefore fosters private sector growth, since with unemployment increasing there is greater competition for jobs and downward pressure on wages; on the other hand, though, unemployment raises the level of taxes per worker, to pay unemployment benefits, thus reducing profits. Assume also that the separation rate is a control variable and is therefore independent of unemployment. When the separation rate is above (below) the hiring rate, unemployment increases (reduces).

As Ferragina and Pastore (2008) argue, although thought to explain national unemployment, this framework might also apply to local labour markets, provided that they are separated from each other due to low migration / commuting. Then, two alternative hypotheses are in order:

$\mathrm{H}_{1}$ : worker reallocation correlates positively with regional unemployment;

$\mathrm{H}_{0}$ : worker reallocation is independent of regional unemployment.

According to $\mathrm{H}_{1}$, in high unemployment regions more jobs are destroyed and created at the same time. In the spirit of the Aghion and Blanchard model, this happens because each region has a specific rate of structural change, but other hypotheses are also possible, as later discussion shows. According to $\mathrm{H}_{0}$, instead, the same aggregate shock has yielded different effects in different regions. High unemployment regions have experienced an unsuccessful process of structural change in the past, with a too high separation rate at the beginning, so that the unemployment rate exceeds its equilibrium level. Only at a later stage separation rates converge across regions. 
In fact, the above hypotheses configures an empirical law to detect the case when unemployment is due to some region-specific shock $\left(\mathrm{H}_{1}\right)$ and when it is due to labour market rigidities $\left(\mathrm{H}_{0}\right)$. The policy implications of these alternative hypotheses are partly different. Whilst a low job finding rate essentially indicates the need for supply side policies in favour of the long-term unemployed, namely increasing labour market flexibility and/or educational reforms and active labour market policy on a large scale, $H_{1}$ also requires interventions on the demand side. For instance, assuming that the government is able to do so, it should reduce the rate of separation and/or increase the life expectancy of private businesses in the high unemployment regions. This might in turn require removing the sources of structural change in high unemployment regions.

The empirical evidence available in the literature is neither large nor unambiguous. The main reason is the limited availability of suitable longitudinal data to measure labour market dynamics at a local level. In addition, the sign of the relation under consideration might change over time.

Robson (2001) finds no correlation between worker reallocation and unemployment across the UK macroregions in the decade 1984-1994. In the case of transition countries, some authors (such as Boeri and Scarpetta 1996; Boeri 2000; the World Bank 2001; Rutkowski 2003) interpret the low rate of monthly labour turnover based on employment registry data of high unemployment regions as a consequence of low labour market dynamism. Other studies find evidence that high unemployment regions are those where the degree of worker turnover is higher. For the UK, Armstrong and Taylor (1985) use the male monthly inflow from the employment registry data and find that they positively correlate to local unemployment rates. Newell and Pastore (2006) use labour force survey measures of annual gross worker flows and find a correlation coefficient between the job separation rate and the unemployment rate of 0.76, significant at the one-percent level, during the period 1994-1997. Contini and Trivellato (2006) find the highest turnover rate in the traditionally high unemployment regions of Mezzogiorno. Naticchioni, Rustichelli and Scialà (2006) find similar evidence using the ISFOL panel based on ISTAT Labour Force Survey data.

The well-known Krugman (1994) hypothesis provides an explanation of $\mathrm{H}_{0}$. It states that the higher is the degree of labour reallocation experienced in a country (region), the lower is also the unemployment rate: greater labour reallocation would mean, in fact, lower frictional and long-term unemployment. In other words, there would be a spatially asymmetric impact of rigid labour market institutions. Extensive literature highlights, among other things, the role of rigid wages and legislation protecting employment, non-employment subsidies and early retirement schemes (see, among others, Boeri 2000; World Bank 2001; Rutkowski and Przybila 2002; Funck and Pizzati 2002; 2003). Garonna and Sica (2000) find a negative association between the Lilien index of structural change and the unemployment rate in Italy: in particular, sectoral and interregional reallocations in Italy would reduce unemployment, rather than increasing it. Böckerman (2003) takes the same result for Finland as evidence of Schumpeterian “creative destruction”.

A related issue is whether it is the inflow or the outflow rate to affect unemployment over time. Blanchard and Summers (1986) claim that a higher degree of cyclicality of the hiring rate is behind fluctuations in US unemployment. Burda and Wyplosz (1994) note that European countries differ in terms of the degree of cyclicality of hiring and firing rates. While some EU countries follow US trends, others, instead, have a cyclical firing rate. Layard, Nickell and Jackman (1991) summarise this research partly confirming the hypothesis that a low job finding rate is behind high unemployment rates, due to the increase in long-term unemployment and its persistent impact on average unemployment. Using micro-level data, Shimer (2007) proposes a new methodology which demonstrates that it is the evolution of the job finding rate - and not that of the flow into unemployment - 
reproduces the cyclicality observed in the unemployment rate ${ }^{1}$. A number of studies have applied Shimer' analysis for other countries establishing similar conclusions (see, among others, Petrongolo and Pissarides, 2008, for the UK, France and Spain; Bachman, 2009, for Germany; and Strawinski, 2009, for Poland).

\subsection{The sources of worker reallocation}

If $\mathrm{H}_{1}$ holds true, what are the sources of the reallocation and why are they different across regions? Several hypotheses have been raised in the literature:
$\mathrm{H}_{13}$ : different sectoral shifts across regions (Lilien hypothesis);
$\mathrm{H}_{12}$ : aggregate disturbances with spatially asymmetric effects (Abraham and Katz hypotheses);
$\mathrm{H}_{11}$ : a crowding out of employed job seekers in low unemployment regions (Burgess hypothesis);

According to $H_{13}$, some sectors/regions experience a permanent reduction in labour demand that causes local unemployment. Lilien (1982) found a positive correlation over time between the aggregate unemployment rate and the cross-industry dispersion of employment growth rates in the US. Most studies use some variation of the Lilien index ${ }^{2}$. However, Abraham and Katz (1986) and a number of related studies (such as Neelin, 1987; Fortin and Araar, 1997) argue against the underlying assumption that sectoral shifts can take place independent of aggregate labour demand reductions ${ }^{3}$.

To overcome these criticisms, the ensuing research in the field has pursued the aim of finding empirical ways of disentangling sectoral shifts and aggregate disturbances. Several approaches have been developed. Neumann and Topel (1991) elaborate a macroeconomic model where the equilibrium level of unemployment in a region depends on its exposure to the risk of within-industry employment shocks and on their degree of industrial diversity. Their approach has stimulated further research (see, for instance, Chiarini and Piselli 2000; and Robson 2009) ${ }^{4}$. Hyclak (1996, p. 655) reports a negative correlation of -0.72 between sectoral shifts and net job growth in a sample of 200 US metropolitan areas over the years 1976-1984. Holzer (1991) proposes the sales growth rates to disentangle shifts between and within local markets and find that the former have much greater impact than the latter.

According to Burgess (1993), the greater worker reallocation in high unemployment regions is due to the lower job opportunities for unemployed job seekers in low unemployment regions. In these regions, in fact, the unemployed are crowded out by employed job seekers who are encouraged to search for better jobs. Consequently,

\footnotetext{
${ }^{1}$ Hall (2007) subscribes to Shimer’s view, while Elsby et al. (2009) and Fujita and Ramey (2009) suggest alternative explanations. Fujita and Ramey (2009) find that cyclical changes in the separation rate is negatively correlated with changes in productivity and move contemporaneously with them, whereas the job finding rate is positively correlated with and tends to lag after productivity, which is consistent with the Aghion and Blanchard (1994) theoretical framework adopted in this paper.

2 Among the available studies, it is worth mentioning Samson (1985) for Canada; Berg (1994), Barbone, Marchetti and Paternostro (1999), Newell and Pastore (2006) for Poland; Krajnyàk and Sommer (2004) for the Czech Republic; Robson (2009, p. 282) for the UK.

${ }^{3}$ There are sources of structural change that tend to be transitory and others that are permanent. The former include the opening up to international trade of new competitors and the introduction of new technologies causing some productions to go out of market. Structural and permanent 'weaknesses' of high unemployment regions, which cause their low competitiveness and attractiveness to investment from abroad, include: a) Low human and social capital endowment; b) High (organised) crime rates; c) Reduction in migration as an adjustment mechanism; d) Economic dependence on more developed regions; e) Poverty traps. For a more detailed analysis, see Caroleo and Pastore (2010).
}

4 The above discussion shows the existence of a clear link between Lilien's argument and Simon (1988) and Simon and Nardinelli's (1992) hypothesis of a portfolio effect in the labour market (see for surveys Elhorst 2003, p. 735). 
one would observe a higher worker turnover in high unemployment regions simply because in these regions the unemployed who find jobs are a larger relative number with respect to their peers in low unemployment regions.

A number of studies have tested the Burgess hypothesis. Van Ours (1995) finds only partial evidence of competition between employed and unemployed job seekers in the Netherlands. Broersma (1997) finds similar evidence in the flexible UK and rigid Netherlands. For the UK, Robson (2001) finds evidence of employed job seekers crowding out the unemployed especially in low unemployment regions. Burgess and Profit (2001) find that high unemployment levels in neighbouring areas raise the number of local vacancies but lower the local outflow from unemployment. Eriksson and Lagerström (2006) study the Swedish Applicant Database and find evidence that unemployed seekers face a lower contact probability than employed job seekers.

In conclusion of this section, it should be noted that no study compares the above hypotheses in the same theoretical framework. Most studies provide instead evidence of only one source or, in several cases, they contrast two hypotheses.

\subsection{The case of Poland}

Transition from a centrally planned to a market economy typically involves massive layoffs and economic slowdown inhibiting vivid job creation. The situation in the early 1990s in Poland was no different, with the registered unemployment rate increasing up to $10 \%$ in just two years and since then never falling below this level (Figure 1). Professional and geographic mobility is very low, while transitory migration of approximately one million Poles to Ireland, Sweden, Norway, Germany, UK and other EU countries as of 2004 concerns predominantly those aged under 30 years old $(80 \%)$ and with relatively high skills (17\% of them have a university degree). Employment in agriculture still exceeds 17\%, which is extremely high by European standards, while half of the registered unemployed live in the rural areas. In addition, forecasts concerning the agricultural sector at large suggest that, due to increasing labour productivity, hidden over-employment in this sector will soon transform to de facto unemployment and/or premature labour market exits. Thus, low mobility and excessive employment in agriculture are the main structural traits of the Polish labour market.

\section{[Figure 1 about here]}

Since the beginning of transition from plan to market, unemployment has taken a strong geographic dimension. However, the differentiation at a regional level is surprisingly low (usually ranging between 3-5 percentage points), while within regional variation may be as high as 11 -fold. As also the early literature on geographical differences in Poland has shown (Gorzelak, 1996), despite the very high degree of dispersion in the local unemployment rate and its persistence over the post-transition period, there has never been any obvious geographical pattern across voivodships or poviats. In other words, different from the UK, Italy or Germany, just to mention some of the best-known examples of clear spatial concentration of high and low unemployment areas, there is neither a North-South nor an East-West divide. Figure 2 shows the geographical distribution of unemployment rates across poviats. Although, the highest unemployment poviats tend to locate in the North-West, West and South-East, some of the highest unemployment local labour markets are neighbouring some of the lowest ones.

\section{[Figure 2 about here]}

This fact has encouraged the literature of the early 1990s to elaborate different classifications of Polish voivodships aimed at testing the impact of the industry structure inherited from the past communist era on the spatial distribution of unemployment. The basic assumption behind these research efforts followed from the 
contention that the transition hit most the regions abundant in inefficient manufacturing plants, where production was established and maintained as a result of political, rather than economic considerations. An index of industrial concentration was used to proxy the level of industrial development, while the share of employment in services, the level of infrastructure and of human capital proxied the current level of development (Gòra and Lehmann, 1995; Scarpetta, 1995; and Scarpetta and Huber, 1995; Lehmann and Walsh, 1999; Walsh, 2003). However, as Newell and Pastore (2006) argue, none of these classifications actually capture the distribution of labour market flows, which makes them only marginally informational about the sources of unemployment rate diversification.

\section{Data}

This paper employs data from three main sources: a) reporting of stocks and flows of registered unemployed by local labour offices (LLOs) for the Ministry of Labour and Social Affairs (ML\&SA); b) the unemployment rate from the Central Statistical Office; and c) control variables from the Bank of Regional Data.

The first source provides the bulk of the data bank. It is very rich, as it refers to 380 poviats (i.e. counties classified in the EU as LAU1 units - 314 land counties and 65 city counties) ${ }^{5}$ over the period from January 2000 to December 2008. The length of the period that the data covers allows us to consider both times of the considerable unemployment growth (2001-2003) and the subsequent decrease (2005 onwards). The data yields an overall number of 40,201 observations coming from monthly reports by each of the LLOs to ML\&SA with detailed information about the stock of the unemployed as well as the size of the flows ${ }^{6}$.

This dataset is a unique source of information in as far as both the duration and the level of detail are concerned. Although the labour force survey has quasi-panel dimension, which could allow computing quarterly labour market flows (Pastore and Socha, 2005), it does so only at a relatively aggregated NUTS2 level of 16 voivodships. However, there are two main reasons why a voivodship level analysis may not be satisfactory. First, the information content of regional aggregates is low, since poviat level unemployment rates exhibit neither stochastic nor sigma convergence to the voivodship averages, which suggests these are indeed diverging processes (Tyrowicz and Wójcik, 2011). Second, it is exactly at the local level that decisions regarding labour market policy are taken today in the country.

A shortcoming of working with poviat data, though, is that only few control variables are available. Nonetheless, additional control variables were obtained. First, the stock of unemployed obtained from ML\&SA data and the unemployment rate from CSO data has been used to compute the labour force (LF) size of poviats. The latter we use as a denominator to normalise stock and flow variables and hence make them quantitatively comparable.

Second, CSO provides the employment composition by broad sectors of activity, namely agriculture, industry and services. The data on employment composition reporting agriculture, industry and services is available only annually and only from 2003. The private ownership share in employment is also available annually for the same years. Moreover, annual data relative to private per capita fixed capital formation is available since 2002.

\footnotetext{
${ }^{5}$ A poviat is the second-level unit of the local government and administration in Poland, equivalent to a county or a district (LAU1 in the EU classification, formerly NUTS4). A poviat is part of a larger unit or province called a voivodship (NUTS2 in the UE classification). In turn a poviat is usually subdivided into gminas (i.e. municipalities or communes). However the more important towns and cities function as separate counties in their own right, with no subdivision into gminas (the so-called city counties). Public employment services have poviat coverage with no separate service centres existing at a gmina level.

${ }^{6}$ Prior to reporting, data is aggregated in each LLO, thus this dataset does not permit individual level analysis.
} 
Finally, we obtained the annual data on personal income tax revenues in poviats for the period covering 19992008. Since PIT is proportional to individual income, it can be taken as a proxy for per capita GDP, which is unavailable. However, tax data is not available for city poviats for the whole analysed time span; while it is only provided at an annual frequency for the land poviats. Unfortunately, since 2004 there has been a considerable increase in the proportion of PIT revenues assigned to the local authorities, which blurs the comparison across years. To address this shortcoming as well as avoid difficulties induced by the nominal character of this variable, we standardise tax data year-wise. This approach still permits to explore the regional variation and eliminates the problems induced by the nature of this variable. Other potentially relevant information is reported only at the voivodship level.

\subsection{Inflows and outflows}

The registry data includes information on two types of flows into the registry and three types of flows out of the registry. The former allows the separation into a group that is registering for the first time (FT), and a group that is re-registering (RR). The data on the outflow permits to observe separately those who find a job (JF), those who are de-listed from the registry for administrative reasons (AD) and those who are temporarily attending active labour market schemes (AS). The total inflow rate in each poviat $i$ at each point in time $t$ is defined hence as a sum of all inflows over the labour force:

$$
\text { Inflow }_{i, t}=\frac{F T_{i, t}+R R_{i, t}}{L F_{i, t}}, \text { Inflow }_{i, t}=\frac{F T_{i, t}+R R_{i, t}}{L F_{i, t}},
$$

whereas the total outflow rate is defined as a sum of all outflows over the labour force:

$$
\text { Outflow }_{i, t}=\frac{J F_{i, t}+A D_{i, t}+A S_{i, t}}{L F_{i, t}} .
$$

The turnover rate is then defined as a sum of the inflow and outflow.

$$
\text { Turnover }_{i, t}=\text { inflow }_{i, t}+\text { outflow }_{i, t}
$$

While it captures well the absolute dynamics in the labour market - as opposed to net flows - such measure is also "blind" to whether these are the inflows or the outflows that differ across units. To inquire which of the flows contribute more to the variation in the unemployment rate, we estimate the model both for the turnover as a whole and with separation of the inflows and the outflows.

Finally, the unemployment rate is



A reason of concern, when dealing with data from LLOs is that the overall flow might not be entirely related to the labour market dynamics, but to administrative reasons as well. To see why, consider that there are three main reasons why individuals register with the LLOs: access to job offers, to unemployment benefits and to health insurance (covering all dependent family members). Only the unemployment benefit is temporary (usually 12 months, never exceeding 18 months) and some of the registered unemployed are not entitled to it at the time of their first registration ${ }^{7}$. Individuals ineligible for the unemployment benefit may apply to the social assistance 
institutions, which provide means tested benefits. Moreover, registration with the social assistance provides health insurance as well. Consequently, in fact, only weak incentives exist to maintain registration with the LLOs.

On the other hand, under the Polish legislation, an unemployed person is obliged to demonstrate "willingness to undertake employment". There is no strict definition of what exactly is expected of the unemployed, but local internal regulations in the LLOs permit their representatives to remove individuals from the registry on various grounds. As a matter of fact, LLOs draft independently internal regulations, which serve as "interpretations" of the country-wide legislation. For instance, in some poviats, an unemployed person may be removed from the registry if he/she refuses to accept a sequence of job offers, irrespectively of their suitability, whereas in some of the poviats employers known for violating the labour remain eligible to post their vacancies and even receive job creation subsidies or apprenticeship financing.

In addition, some of the LLOs are temporarily or permanently subjected to incentives to abuse the discretionary power of "de-listing" for fiscal and organisational reasons. These incentives originate from the conflict between different financing schemes. On one hand, the higher is the number of registered unemployed, the larger is the state-level financing for active labour market policies. On the other hand, local authorities - who supervise public employment services and are obliged to bear all the payroll and institutional expenses occasionally exert pressure to decrease headcount in the respective LLO as well as the number of registered unemployed for both financial and political reasons. Either of these effects is likely to dominate temporarily in a particular poviat. Consequently, there is considerable heterogeneity relative to how the legislation is being implemented.

Summarising, some of the movements into and out of the registry can be called "administratively driven flows" as distinguished from the market-driven flow and might affect the results. To take into account this possible source of bias, the analysis will distinguish turnover due to "market driven flows" (MDF=JF+FT, i.e. outflows to employment and first-time registrations, respectively) from turnover due to "administratively driven flows" $(\mathrm{ADF}=\mathrm{AD}+\mathrm{AS}+\mathrm{RR}$, i.e. de-listings for administrative reasons, participation in activisation schemes and reregistrations, respectively).

Of the administratively driven flows, re-registrations capture partly job losers and quitters who have been registered at any moment in time since $1994^{8}$. While participation in activisation schemes is of minor scale (cfr. Table 1), it covers undoubtedly a group that is not working in the reporting month. Thus, to recognise that part of the flows is driven purely by administrative decisions (AD and AS), an additional, adjusted unemployment rate measure has been computed as:

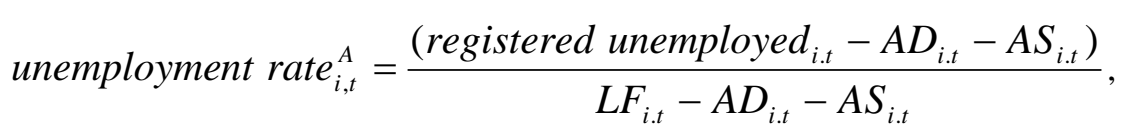

In fact, as Table 1 shows, while AS is of minor scale, the administratively driven flow is overall of considerable size. As a consequence, assuming that it correlates to the local unemployment rate with a different sign from the overall inflow and outflow, it might affect changes in the local unemployment rate in a way that is not related to the theoretical underpinnings of this study. The hypothesis underlying empirical testing certainly concerns market driven adjustment, rather than administrative factors. Consequently, we pay particular attention in the estimations to disentangling these two effects, to the extent that data quality permits it.

\footnotetext{
${ }^{8}$ In 1994 the New IT system covering the unemployment services has been established, while subsequent modifications have built on this original database. Thus, unemployed registered ever since 1994 will appear as a re-registering individual, no matter what the reason for de-registration (administrative delisting, finding employment, etc.).
} 


\section{[Table 1 about here]}

There are two main limitations of the corrections for administratively driven flows checks. First, a minor but potentially pivotal part of the flows - although administratively driven - might in fact correspond to ones individual labour market situation (e.g. discouraged workers stop reporting to the employment office and are thus de-listed, but within few months their situation may change inducing more effort to find a job, which implies a subsequent reregistration). To address the relevance of administrative factors we check whether they affect the results of the econometric analysis.

Second, administratively generated flows may affect the findings in a way that is not possible to predict $a$ priori. Two possible hypotheses are in order: on the one hand, some offices might wish to excessively de-list people from the register to show that their policy against unemployment was successful; on the other hand, other offices might wish to keep the unemployed in the register to justify the request of funds and maintenance of office headcount. Moreover, local labour markets with higher unemployment rates tend to have also a higher incidence of long-term unemployed, who are more frequently "de-listed" for purely administrative reasons. At the same time, though, the majority of the individuals who are removed from the registry for administrative reasons re-register after a penalty period ${ }^{9}$. Which of these tendencies is prevailing is a matter of empirical testing.

\subsection{Clusters of poviats}

Considering the high heterogeneity of local units, following previous research, it is crucial to verify the robustness of the results to the potential clustering of poviats sharing similar structural characteristics. Typical way to address this problem in the spirit of Aghion and Blanchard (1994) model would be to compute the Lilien Index and include it as a control variable. Unfortunately, there are no variables available at a poviat level to obtain values of LI for the whole time span covered by the paper ${ }^{10}$. While employing the index directly in the computations would reduce the sample to just two years of data (2004-2005), we may nonetheless use it an indication of which poviats are typically characterised by more structural adjustment than others. We then combine these results with additional data available for poviats and propose a type of stratification strategy.

While the values of Lilien Index are in general relatively high, we may discern the groupings of poviats with extreme and moderate scores. However, it would be rather reckless to assume that a value of Lilien Index over only two years in the sample is symptomatic of the whole analysed period. We thus coupled this information with data on overall change in the structure of employment and ownership over a longer time span. For example, poviats which ranked among the lowest in service employment in 2003 and among the highest in 2008 have naturally undergone continuous significant structural change. On the other hand, poviats with the lowest share of private ownership, the lowest investment rates and the highest employment share in agriculture can be identified as relatively resistant to transition forces.

For the reasons of data availability, the stratification is based on four variables: the share of private firms in employment, the share of services and agriculture in employment and the investment intensity. The following groupings of poviats have been identified:

a) LAGGARDS - [44 poviats] with low private ownership (bottom 25\%), high share of rural employment (top 25\%) and low investment rate (bottom 25\%)

\footnotetext{
${ }^{9}$ The correlation coefficient between de-listings and re-registrations is of roughly 0.74 and highly significant from a statistical point of view.

${ }^{10}$ For the same reason we were unable to replicate the classifications of Gòra and Lehmann (1995); Scarpetta (1995); Scarpetta and Huber (1995); Lehmann and Walsh (1999) or Walsh (2003).
} 
b) IN TRANSITION - [74 poviats] with both high rural and service share in employment (top 25\% in both)

c) PRIVATISED INDUSTRIAL - [66 poviats] with high private ownership (top 25\%) and high industry contribution (top 25\%)

Naturally, poviats "travel" across the quarters of variables distribution, while this migration is also endogenous to the labour market turnovers. Thus, we use the earliest available data (2003 for employment shares, 2002 for investment) which partially addresses the problem of the mutual reinforcing between the structural change and the labour turnover. In addition, these classifications are not mutually exclusive in the sense that the same poviat may belong to more than one group, while some poviats may appear in none of the groups. The purpose of this grouping, however, has not been to classify all the poviats, but rather to distillate those, who are more likely to expect larger (INDUSTRIAL, IN TRANSITION) or smaller (LAGGARDS) structural change.

To corroborate the adopted typology we report below the average values of Lilien Index for the available years within the identified clusters, Table 2 . In all of the cases where relatively larger industrial restructuring is expected (IN TRANSITION, INDUSTRIAL), the Lilien Index is larger than average in a statistically significant way. Moreover, for the LAGGARDS group it is also smaller in a statistically significant way. Consequently, the adopted stratification seems to reflect well the level of industrial restructuring.

\section{[Table 2 about here]}

\section{Methodology}

This paper aims to study whether the regional variation in unemployment rates is related to regional variation in the labour turnover. In addition, the paper aims to assess the relative impact of inflow and outflow from unemployment on the dynamics of the local unemployment rate. According to $\mathrm{H}_{0}$ in Section 1 , large turnover is consistent with more flexibility, thus implying that it could be associated with lower unemployment (frictional unemployment gets reduced faster). On the other hand, according to $\mathrm{H}_{1}$, large turnover is also consistent with more structural change, suggesting that larger turnover could also be associated with higher unemployment (structural unemployment is larger). The theoretical predictions discussed in the previous sections suggest the following formulation of the model to be estimated:

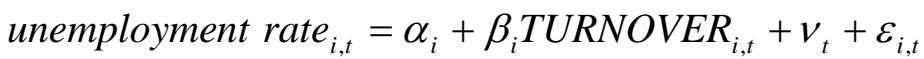

and, alternatively,

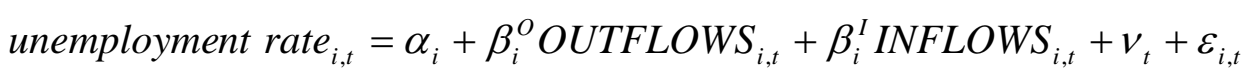

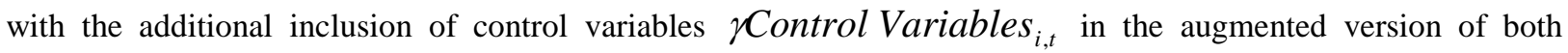
equations. $\mathrm{H}_{0}$ will then imply that $\beta_{i}=\beta_{i}^{I}=\beta_{i}^{O}=0$ against the hypothesis that all those coefficients be positive in $\mathrm{H}_{1}$. The key aspect of the analysis concerns the cross-sectional correlation between the variables of interest. This correlation is however a priori plagued in the type of longitudinal data we have by a number of possible technical econometrics issues to address. The first one is the natural autocorrelation in the unemployment rate. A robust Newey-West panel data estimator with time fixed effects is used to tackle this problem. For each point in time, this estimator will essentially allocate to the fixed effect the entire time specific component, allowing the model parameters to capture the variation that is attributable to poviats. 
There are three additional possible weaknesses of this methodology, though. The first one is a bias attributable to the spatial effects associated with the labour market processes. For example, although a person is registered as unemployed in a high(low) unemployment poviat, geographically (s)he may be closer(further) to a dynamic, low unemployment poviat and thus have more(less) chances to obtain a job. Consequently, unemployment level in a poviat and its neighbouring poviats encompasses also outcomes of individuals' geographical mobility, which necessitates spatial spillovers. Thus, accounting for geography is crucial for testing the reliability of the findings. Second, the model - being a single equation one - naturally involves explanatory variables that are not strictly exogenous and heterogeneity of an a priori unknown form ${ }^{11}$. While spatial issues may result in a bias of the estimated coefficients - potential endogeneity may contribute to the inconsistency of the estimated coefficients and potential heteroscedasticity implies that the estimated standard errors may be unreliable.

To address the first problem identified above we employ spatial econometrics. Namely, based on the adjacency of poviats we compute a typical spatial weights matrix ${ }^{12}$. We focus on the quantitatively most important source of the potential spatial effects - spatial lag dependence (Anselin, 1988). Spatial lag dependence can occur when there are spatially correlated omitted variables, spatially correlated aggregate variables or spatially correlated errors in variable measurement. Ex ante we cannot rule out any of these three sources of spatial error dependence, we thus adopt a geography weighted regression to the explanatory variables to account for potential bias in addition to the standard panel estimations.

There are several ways to handle the potential dynamic panel bias - the second problem in our estimations. It is known that LSDV does not address the potential endogeneity of other regressands ${ }^{13}$, but conveniently Generalized Method of Moments (GMM) does so in this context ${ }^{14}$. More specifically, fixed time effects estimators do not permit to observe the changes invariant in time and neither will GMM estimation. However, the regressands of particular interest - measures of turnover - are likely to be endogenous to the unemployment rate. Our dynamic model provides three main reasons for correlation in unemployment rate over time: directly through the values of unemployment rate in the preceding periods; directly through observables (i.e. observable heterogeneity) and indirectly through the time-invariant individual effect (i.e. the unobservable heterogeneity). The potential correlation between the error term and the individual effect makes the panel estimation inconsistent. AndersonHsiao (1981) estimator uses the second lag as an instrument after first-differencing the model to be estimated, while Arellano and Bond (1991) argue that model performance may be improved if additional lags are introduced. Additionally, Huber-White sandwich estimator of variance allows obtaining robust standard errors.

This estimation may be implemented as a less efficient - but also less demanding - IV model or in a two-step version offering more efficient estimators of standard errors. However, the moment conditions of this type of GMM

\footnotetext{
11 Throughout all the estimations heteroscedasticity consistent Newey-West standard errors estimation is used. Technically speaking, we use an adequate adaptation of the initial Newey-West variance matrix estimator that is relevant for a particular model.

${ }^{12}$ For each poviat we obtained the data on adjacency denoted by 1 in a a kxk matrix, where $\mathrm{k}=380$ poviats. Each row (and column) in this matrix was subsequently normalised to unity, by dividing by its row (and column). This matrix was subsequently used to reweigh the values of the independent variables used in the estimations, cfr Anselin (1988).

${ }^{13}$ Comprehensive surveys of these estimators can be found for instance in Arellano and Honore (2001) or Blundell, Bond and Windmeijer (2000).

${ }^{14}$ In order to adequately establish the structure of the GMM estimation, we first estimate a simple dynamic model. This allows understanding better the dynamics of the process, thus yielding the boundaries for the structure of the estimation. As expected, the first lag of the dependent variable in the OLS regression is correlated with the fixed effects in the error term, creating dynamic panel bias (Nickel 1981). After accounting for the fixed effects in the model, the initial naive GLS regression demonstrates that the lagged dependent variable is positively correlated with the error, biasing its coefficient estimate upwards, and for the within groups, the opposite effect is observed.
} 
estimator are only valid if serial correlation is not present in the idiosyncratic errors. But the first difference of white noise can be autocorrelated, so the second and higher autocorrelations should receive more attention. In our results, there is no evidence of serial correlation in the first-differenced errors at order 2, so the moment conditions used are valid. Secondly, in order to perform a two-step GMM estimation, the model needs to be overidentified. In fact, this requirement is satisfied in our model. Namely, the availability of the monthly data permits the use of multiple lags as instruments without a major loss in the sample size ${ }^{15}$. Consequently, as the best strategy, we obtain the classic Arellano-Bond (1991) GMM estimator, which uses moment conditions in which lags of the dependent variable and first differences of the exogenous variables are instruments for the first differenced equation. To complete these estimations, we also employ the so-called SYS-GMM, as suggested by Arellano and Bover (1995) as well as Blundell and Bond (1998). This specification allows the use of first lags as additional instruments in the differenced equation. System GMM estimator is believed to obtain more precision and better finite sample properties thanks to using this additional lag, Doornik, Arellano and Bond (2002).

The final attempt to tackle the consequences of endogeneity and the time-induced estimation flaws consists of a simple approach, possible due to the richness of the dataset. Namely, we resort to using only 2000 annual averages for the right-hand side variables (turnover as well as inflows and outflows) and 2008 annual averages for the dependant variable (unemployment rate). In addition, both RHS and LHS variables have been standardised to asymptotically $\mathrm{N}(0,1)$ distribution. This way the absolute level of unemployment is no longer relevant in the estimations, neither are the absolute values of turnover, inflows and outflows. Consequently, we explore a crosssectional dimension, without running the risk of endogeneity (LHS variables precede RHS by 8 years, while the level of absolute unemployment rate in 2000 and in 2008 were roughly comparable, compare Figure 1).

It is possible that while we account for spatially driven heterogeneity and employ robust standard errors, there are also other sources of heterogeneity that prevail. To address this issue we propose two additional estimations. First, obtain estimates separately by the decimal groups of the unemployment rate to capture the heterogeneity attributable to the severity of the local labour markets situation. Second, clustering of poviats based on industrial restructuring provides another way to check if heterogeneity substantially influences the standard errors obtained for the total sample.

\section{Results}

This section is organised in three parts: (i) description of data properties; (ii) estimates for the overall sample and (iii) robustness checks. The robustness checks, as discussed earlier, is based on spatial lag inclusion as well as clustering of poviats to account for potential distributional effects associated with the unemployment rate and clustering of poviats to account for the structural differences among them.

\subsection{Data properties}

Table 3 supplies descriptive statistics of the variables used in the econometric analysis. All numbers in the table represent averages over the entire period. "Industrial" poviats include the largest stock of unemployed but the lowest unemployment rate, which suggests that these are relatively large local labour markets with a more dynamic economy. In fact, this group includes virtually all city poviats as well as other densely populated and urbanised

\footnotetext{
${ }^{15}$ In fact, this would not have been possible with the annual data, because T (i.e. the number of periods) would have been relatively small (only ten years of observations). Implementing the Arellano-Bond estimator would effectively imply the loss of at least three years, i.e. nearly a half of our sample. Moreover, the requirement of overidentification would have been violated, necessitating the use of less efficient one-step estimator. Thus, we resort to monthly data only.
} 
poviats. As expected, the poviats "lagging behind" include some of the least densely populated regions and also those with the highest unemployment rate. The "transition" cluster is more similar to the "laggards" than the "industrial". Note that the average unemployment rate in the sample is lower than the average unemployment rate in each cluster of poviats.

\section{[Table 3 about here]}

Panel (a) of Figure 3 provides scatters of inflow and outflow rates by year for all the poviats in the sample. Both components of labour turnover present a high degree of variation, over time and across units. Nonetheless, they positively correlate with each other in every year. This depends on the nature itself of labour market dynamics, which always tends to fluctuate around some equilibrium unemployment level. Nonetheless, at a careful glance, it appears that the slope of the scatters tends to be flatter (steeper) when the unemployment rate is increasing (reducing). Overall, this is as if it was not the gap in inflow or outflow rates, but the gap in both flows, or in the turnover rate, as suggested in the theoretical hypotheses discussed in section two, that correlates with the gap in unemployment rates. Panel (b) of Figure 3 shows the same variables as in panel (a), but organised by voivodship. Again, the correlation is always positive, although in some voivodships the slope is steeper than in others.

\section{[Figure 3 about here]}

The correlation between inflow and outflow is confirmed by inspection of Figure 4 which reports the average levels of monthly inflow, outflow and unemployment rates by voivodship. The former two are measured on the leftside, while the latter is measured on the right-side of the figures. Clearly, the data shows that the unemployment rate is reducing when the inflow overcomes the outflow from it; and vice versa. However, in addition to the time dimension, visual inspection reveals that there is also a high correlation in the rates of inflow, outflow and unemployment across regions. In fact, while the time effects are a natural phenomenon, it is the cross-sectional dimension that could possibly allow testing the theoretical hypothesis discussed in the previous sections. Thus, exploring the cross-sectional variation lies at the core of the analysis in the reminder of this paper.

\section{[Figure 4 about here]}

\subsection{Results of the estimations}

Table 4 reports the results of the time fixed effect panel GLS estimator with robust standard errors. All the variables are in logarithms and therefore the coefficients measure elasticities. All the estimations are performed on the raw (columns from 1 to 7) and adjusted data (columns from 8 to 14). As described in Section 3, the former are the originally reported unemployment rate as well as the turnover rate, whereas the adjusted data do not take into account the administratively de-listed (see equations $3 \mathrm{a}$ and $3 \mathrm{~b}$ ). In addition to the specification using labour turnover only as the regressor of interest (columns 1 and 8), the following ones disentangle labour turnover in different components: (i) inflow and outflow (columns 2 and 9); (ii) individual components of the flow (columns 3 and 10); (iii) market and administratively-driven flow (columns 7 and 14). The following columns - from 4 to 6 and from 11 to 13 - repeat the same previous estimates including the available control variables.

The results show a consistent positive and statistically highly significant coefficient for the rate of labour turnover and also for inflows and outflows in both the raw and adjusted data, although the outflow rate has a much smaller coefficient. The positive coefficient of outflows catches the correlation between above average unemployment rate and above average outflows, confirming that in fact what matters while explaining the crosssection dimension of variation in unemployment rates is the overall degree of turnover, rather than the size of the outflow. 
The size of the estimated elasticity is consistent across specifications, but slightly lower in the case of adjusted data. This last finding suggests that administratively driven outflows contribute negatively to the unemployment rate and considering their large size, this is indication for policy makers that registered unemployment might partly be affected by the behaviour of local labour offices. This is confirmed upon inspection of elasticity of the $\mathrm{AD}$ variable. Ceteris paribus, across all specifications on the raw data it is negative and statistically significant, although the point estimator is fairly low. This is circumstantial evidence that the AD flow is used by LLOs to artificially “adjust” the unemployment rate especially in high unemployment regions ${ }^{16}$.

\section{[Table 4 about here]}

The differential between the coefficients of inflow and outflow shrinks when we move from raw to adjusted data. In fact, larger responsiveness of the unemployment rate towards inflows may stem from two sources. First, we are not exploring the time dimension but the cross-sectional dimension, which implies that this finding is equivalent to statement: regional differentiation of the unemployment rates across poviats is driven more by the asymmetric response to economic shocks exhibiting in the increases of the unemployed pool rather than by the recovery outflows from the registry. This finding is consistent with Armstrong and Taylor (1985). Second,.as already discussed earlier, poviats with higher unemployment rate are typically those with larger shares of long-term unemployed, who tend to drop out of the registry and re-register more frequently than other unemployed. This assertion is partly confirmed by the change in estimators when adjusted data are analysed.

This last assertion is even further corroborated by the analysis of five flows separately. There is naturally a consistently negative contribution from the administrative de-listing (AD) and - quantitatively minor - from the flows into activation measures (AS). This is hardly surprising as it suggests that de-listings are done in such a way to reduce the unemployment rate. In addition, the flow to activation is marginally greater the higher is the local unemployment rate. On the other hand, market driven flows of job finding (JF) and first time registrations (FT) have both a positive sign and are of a comparable size. This finding remains essentially the same for the adjusted unemployment rate and flows, with the size of the elasticity estimates quantitatively comparable. Consequently, it seems that indeed markets with larger market-driven turnover are the ones with higher unemployment rates, which provides empirical support to the Aghion and Blanchard (1994) hypothesis. Also re-registrations contribute positively to unemployment.

Including our control variables does not change qualitatively the findings, though it slightly changes some of the coefficients. The coefficient of labour turnover is slightly reduced, confirming that the controls used do have an impact on the relationship between unemployment and labour turnover. The coefficients of the control variables are as expected. The poviats experiencing an increase in capital availability relative to the rest of the country tend to also have a lower than average unemployment rate. On the other hand, the service sector seems to provide less stable jobs than industry or agriculture, thus yielding higher turnover and unemployment rate. The relative wealth, as proxied by the standardised tax revenues, seems to be associated with higher unemployment rates, ceteris paribus. However, this finding is a consequence of the fact that tax data are not available for the city poviats. It thus

\footnotetext{
${ }^{16}$ Considering the incentives, this problem should be particularly severe there. The pressure to deliver achievements in the fight against unemployment is higher, but at the same time the risk of losing state funds for active labour market schemes are much lower, since financial allocations are proportional to the relative situation of poviats. Thus, if administrative adjustments do not improve the official indicators to an extent sufficient for changing the ordering of poviats in the regional rankings, the loss in available financing may indeed be marginal. Moreover, demonstrating reduction in the headcount of the unemployed may indeed be a way to justify the expenditure of public resources.
} 
seems that among the land poviats, higher wealth is associated with larger labour market dynamics and thus higher unemployment rate ${ }^{17}$.

Although the findings seem stable and consistent across specifications, with the heteroscedasticity as well as with the risk of endogeneity, panel GLS with fixed time effects may result in inconsistent estimators and unreliable standard errors. To evaluate empirically the severity of their consequences, we also employ alternative specifications of the GMM estimation. Naturally, GMM focuses more on the "within” or time-dimension, but it also provides a reliable estimate of how the GLS estimators may be biased vis-à-vis this dimension. Table 5 reports the results of alternative GMM specifications.

\section{[Table 5 about here]}

In fact, GMM estimators differ considerably in size, but are consistent. Namely, over time the coefficients for outflows is both significant and negative, while inflow remains positive. Since over the analysed period, inflows quantitatively dominated outflows and vice versa for a comparable duration (Figure 4), the estimator on turnover is insignificant. However, the lowering of the estimator sizes raises doubts in the reliability of these estimates. Namely, it seems that instruments - lags and differences of turnover, inflows and outflows in respective specifications - have relatively low power, in capturing the cross-sectional dimension. Thus, it seems that GMM both system and difference specifications - tackle well the time-dimension, but not necessarily the cross-sectional variation. What follows, is that the negative consequences of the autocorrelation induced by the time dimension of the data are effectively reduced - if not removed - due to the large size of our sample, whereas unit-driven heteroscedasticity is better tackled by the robust GLS estimator than the GMM (even with the correction for robust variance covariance estimator in both one-step and two-step Arellano-Bond estimations). Nonetheless, we find again that the estimator of the inflows coefficient is again larger than the one of the outflows in a statistically significant manner, which further corroborates the findings discussed earlier ${ }^{18}$.

Summarising, GMM results demonstrate - mainly by exploring the cross-sectional dimension of the data - that turnover as well as both inflows and outflows are positively correlated to the unemployment rate. Leaving aside the ambiguous question of causality, this relationship is robust to the inclusion of other control variables as well as measure of labour market flows and unemployment rate. In fact, correction for the administratively driven flows as imperfect as it is, no better way is accessible for the lack of data - changes the size of the point estimators, but not the main conclusion. Furthermore, the analysis demonstrates that the elasticity vis-à-vis inflows is considerably larger than that of outflows. Since this effect virtually disappears if only market driven flows and adjusted unemployment rate are analysed, it points to the relevance of the administratively driven flows - especially the reregistrations - in determining in the unemployment rate disparities observed in Poland. In the reminder of this section we verify if these results are susceptible to spatial phenomena, statistical deficiencies or outliers.

\subsection{Robustness checks - spatial analysis}

To verify if the results are robust to the inclusion of spatial controls, we perform a robustness check with spatial analysis. Results are reported in Table 6. In fact, both the size and the sign of the estimators on turnover as well as inflows and outflows - remain essentially unaffected by the inclusion of spatial controls. Thus, the main results of

\footnotetext{
${ }^{17}$ Specific results for only city poviats are also in line with the main findings. Detailed results available upon request.

${ }^{18}$ In fact, as expected, in all cases the specification proves to provide consistent estimators. Namely, the null hypothesis of autocorrelation is not rejected at order 1 , but is rejected at higher orders. Moreover, in the standard Sargan test the null hypothesis concerning the validity of overidentifying restrictions (i.e. that the population moment conditions are correct) has not been rejected, either.
} 
this study are not driven by geographical phenomena - the estimations correlations between unemployment rate and turnover are in fact robust and reliable.

Nonetheless, the data support the existence of spatial effects as well. We find a positive spatial lag of turnover on original data and negative spatial lag of this variable on adjusted data. This seems to suggest that when public employment services discretion is controlled for, if surrounded by high turnover poviats, a local labour market is characterised by lower unemployment rate. In fact, this is consistent with intuition which suggests that more dynamic labour markets surrounding a particular location contributes to lowering its unemployment rate.

\section{[Table 6 about here]}

Analysis of turnover components further corroborates this conclusion. Spatial effects of inflows are negative and significant, suggesting that with the increasing inflows in the neighbouring regions, unemployment rates tend to decrease. This effect is counterintuitive, but seems to be driven by metropolises. In the case of large cities, reductions in job demand are equivalent to either overall job destruction or a shift of demand towards cheaper workers inhabiting the surrounding poviats. However, when large cities are no longer included in the estimation (column 5 of Table 6), the spatial effect is significant and conforms to the intuition of unemployment increases spilling over the entire area. The spatial effects of outflows, on the contrary, seem to be independent of the metropolises effects. Namely, for adjusted data it is insignificant, whereas the original data suggest positive and significant estimators, which is consistent with the anecdotal evidence that local labour offices refuse to share collected vacancies and information on job creation. Moreover, the fact that adjusted data no longer lend support to spatial effects, seems to suggest a spurious relationship (these are the administrative delistings that drive the significance of estimators).

\section{4. Robustness check - outliers and unobserved heterogeneity}

Since the data set is so rich, stratification or grouping permits exploring further the cross-sectional variation and does not hazard the statistical quality of the findings. At the same time, for the lack of adequate data, we were not able to directly include indicators such as industrial restructuring or relative physical and human capital abundance. Thus, although the results have proven robust across the specifications, we pursue to verify if they are not driven by specific types of poviats. As suggested earlier, two types of the robustness checks were performed: (i) stratification and (ii) the analysis along the distribution.

First, we have selected poviats, where the industrial restructuring process has been more intense, the so-called INDUSTRIAL cluster. The TRANSITION cluster are intermediate cases. Finally, LAGGARDS are the poviats were industrial restructuring has been least intense than average. The robustness consists of inspecting the differences in the estimated point coefficients across these groups. Table 7 reports the results of stratification analysis for the two preferred specifications, including additionally the spatial controls.

\section{[Table $7 \mathbf{a}$ and $7 \mathbf{b}$ about here]}

The stratification analysis reveals that in fact elasticity estimators are consistent and of the same sign irrespective of the grouping - the differences concern only the size of the estimator. Moreover, the inclusion of spatial dependence does not alter these findings. More specifically, estimators are the largest in the INDUSTRIAL cluster, i. e. the ones where industrial restructuring can be expected to be the highest. Not surprisingly, considering the way clusters have been defined, we also find that the coefficient of the service sector employment variable not statistically significant. In addition, we also find that the difference between the estimators of the inflows and the outflows elasticities is no longer as large as in the case of the total sample. In addition, the differences between the 
effect of labour market turnover and the institutional turnover is largest for the INDUSTRIAL cluster. Finally, it seems that "active de-listing" seems to be particularly at play in this group of poviats, since this is the only estimation where institutional turnover exhibits a negative elasticity towards the unemployment rate.

Another robustness check employed in this paper bases stratification on the unemployment distribution. This analysis consisted of estimating the coefficients on turnover, inflows and outflows at different deciles of the distribution of poviat unemployment rates at the beginning of the analysed period. In fact, poviats rarely change these decimal groups, while most of the mobility is found in the middle of the distribution, which suggests that (i) grouping based on the initial unemployment rate is valid for the whole period of analysis (Tyrowicz and Wójcik, 2010a).

\section{[Figure 5a, 5b and 5c about here]}

Panel (a) of Figure 5 displays the estimated elasticity and confidence interval on the turnover, as represented by the length of the shaded area. The panels (b) and (c) contain the elasticities for inflows and outflows, respectively. Clearly, all the coefficients are statistically significant and of the same - positive - sign. However, the effect is much stronger among the poviats with the lowest unemployment rate and the difference in the size of the estimated coefficient is statistically significant between the lowest unemployment decimal group and the rest of the sample for all the estimators. This finding is in a sense intuitive - in the low unemployment regions the current changes in job creation and destruction give a more decisive contribution to unemployment. In the regions with higher unemployment rates, the accumulated stock of unemployed is actually large enough to make the flows quantitatively less important for determining the unemployment rate. Thus, although the strength of the effect is visibly different along the distribution of unemployment, it is also consistently of the same sign and statistically significant for all deciles.

One additional - and final - attempt to verify the reliability of the results consisted of plotting the variables of interest (i.e. turnover, inflows and outflows) as recorded in the beginning of the time span (i.e. annual averages for 2000) against the unemployment rate at the end of the time span available for the analysis (i.e. the annual averages for 2008). In fact, the aggregate unemployment level in 2000 and in 2008 were fairly similar, but doubled in between these time boundaries.

Figure 6 displays the scatter plots of the unemployment rate in 2008 on the vertical axis against the turnover (panel a), inflows (panel b) and outflows (panel c) by poviats. Each of the graphs is consistent with the statistical findings reported earlier. Namely, poviats with relatively larger turnover, inflow and outflow in 2000 are characterised by relatively larger unemployment rate in 2008. This finding also further undermines the reliability of the GMM estimates - the negative sign of the outflows and turnover estimators seems to find little justification in the graphical analysis of the data.

\section{Concluding remarks}

The empirical analysis of this paper builds on a theoretical model by Aghion and Blanchard (1994). The previous literature brings to the fore different hypotheses as to the link between local labour market dynamics - as proxied by the turnover rate - and the unemployment rate. The theoretical framework as well as the empirical analyses are consistent with predictions in favour of positive, negative and virtually no relationship between these variables. In this paper an attempt was made to quantitatively verify the empirical pattern linking the labour market turnover and the unemployment rate using a rich dataset encompassing nearly 10 years of monthly data. We resort 
to a policy relevant level of a poviat (county). We find a statistically significant and economically large positive estimator on turnover as a whole as well as its components: inflows and outflows.

Leaving aside the question of the causality direction, we have focused on exploring the cross-sectional dimension of the data. There is no clear spatial pattern of the unemployment rate in Poland, while unemployment rate differentials are extremely high and persistent. The empirical findings lend support to the assertion that the larger is the labour market dynamics in the local labour markets, the higher is the unemployment rate. This is evidence of the fact that also in the 2000s, unemployment has been essentially driven by structural change.

The policy implications of our findings are far reaching. In fact, providing empirical evidence in support of the Aghion and Blanchard (1994) model suggests that the key to reducing the unemployment rate lies not only in supply side policies, but also on demand side policies aimed at reducing the degree of structural change or at cushioning it with the support of private or state investment aimed at reducing the persistent causes of weakness or low attractiveness of high unemployment poviats. This implies that instruments addressing the needs of the longterm unemployed, educational reforms and active labour market policy on a large scale are necessary.

Indirectly, these finding may also be interpreted as evidence of the inefficiency of local labour market institutions, whose role should be to smoothen the job-to-job as well as unemployment-to-job flows. In fact, there seems to be little evidence of the ability of high unemployment regions to generate stable jobs. 


\section{References}

Abraham, K. G. and Katz, L.F. (1986). Cyclical Unemployment: Sectoral Shifts or Aggregate Disturbances?. Journal of Political Economy, 94(3): 507-522.

Aghion, P. and Blanchard, O. (1994). On the Speed of Transition in Central Europe. NBER Macroeconomics Annual, 283-320.

Anderson, T.W., and C. Hsiao. 1982. Formulation and estimation of dynamic models using panel data. Journal of Econometrics, 18: 47-82.

Anselin, L. (1988), Spatial econometrics: methods and models, Kluwer Academic, Boston

Armstrong, H. and Taylor, J. (1985). Spatial Variations in the Male Unemployment Inflow Rate. Applied Economics, 17(1): 41-54.

Arellano, M. and B. Honore (2001), Panel Data models: Some recent Developments, in J.J. Heckman and E.E. Leamer (eds), Handbook of Econometrics, Vol. 5, North-Holland.

Arellano, M., and S. Bond. 1991. Some tests of specification for panel data: Monte Carlo evidence and an application to employment equations. Review of Economic Studies 58: 277-97.

Bachman, R. and D. Peggy, (2009), The Importance of Two-Sided Heterogeneity for the Cyclicality of Labour Market Dynamics, SFB 649 Discussion Papers, Humboldt Universität, Berlin, Germany,

Barbone, L., Marchetti, D. J. and Paternostro, S. (1999). The Early Stages of Reform in Polish Manufacturing. Structural adjustment, Ownership and Size. The Economics of Transition, 7(1): 157-177.

Blanchard, O. J. and Summers, L. (1986). Hysteresis and the European Unemployment Problem. NBER Macroeconomics Annual, Ch. 1: 1-78.

Blundell, R., and S. Bond. (1998) “Initial conditions and moment restrictions in dynamic panel data models”. Journal of Econometrics 87: 11-143.

Blundell, R., and S. Bond. 1998. Initial conditions and moment restrictions in dynamic panel data models. Journal of Econometrics 87: 11-143.

Blundell, R., S. Bond and F. Windmeijer. (2000). "Estimation in dynamic panel data models: improving on the performance of the standard GMM estimator.” in B. Baltagi (ed.), Nonstationary Panels, Panel Cointegration and Dynamic Panels, Elsevier Science.

Berg, A. (1994). Does Macroeconomic Reform Cause Structural Adjustment? Lessons from Poland. Journal of Comparative Economics, 18(3): 376-409.

Bond, S. 2002. "Dynamic panel data models: A guide to micro data methods and practice”. Working Paper 09/02. Institute for Fiscal Studies. London

Böckerman, P. (2003). Unraveling the Mystery of Regional Unemployment in Finland. Regional Studies, 37(4): 331-340.

Boeri, T. (2000). Structural Change, Welfare Systems, and Labour Reallocation. Lessons from the Transition of Formerly Planned Economies. Oxford: Oxford University Press.

Boeri, T. and Scarpetta, S. (1996). Regional Mismatch and the Transition to a Market Economy. Labour Economics, October, 3(3): 233-254.

Broersma, L. (1997). Competition between Employed and Unemployed Job Searchers: is there a Difference between the UK and the Netherlands?. Applied Economic Letters, 4(3): 199-203.

Burda, M. and Wyplosz, C. (1994). Gross Worker and Job Flows in Europe. European Economic Review, 38(6): 1287-1315.

Burgess, S. M. (1993). A Model of Competition between Unemployed and Employed Job Searchers: An Application to the Unemployment Outflow Rate in Britain. The Economic Journal, 103(420): 11901204.

Burgess, S.M. and Profit, S. (2001). Externalities in the Matching of Workers and Firms in Britain. Labour Economics, 8(3): 313-333.

Caroleo, F. E. and F. Pastore (2010), "Structural Change and Labour Reallocation across Regions. A Review of the Literature”, in F.E. Caroleo and F. Pastore (eds.), The Labour Market Impact of the EU Enlargement. A New Regional Geography of Europe?, Physica Verlag, Heidelberg, pp. 17-48. 
Chiarini, B. and Piselli, P. (2000). Unemployment, Wage Pressure and Sectoral Shifts: Permanent and Temporary Consequences of Intersectoral Shifts. Journal of Policy Modelling, 22(7): 777-799.

Contini, B. and Trivellato, U. (2006). Eppur si muove. Dinamiche e persistenze nel mercato del lavoro italiano. Bologna: Il Mulino.

Doornik, J.A., M. Arellano, and S. Bond. 2002, Panel data estimation using DPD for Ox, http://fmwww.bc.edu/ecp/software/ox/dpd.pdf

Elhorst, J. P. (2003). The Mystery of Regional Unemployment Differentials. Theoretical and Empirical Explanations. Journal of Economic Surveys, 17(5): 709-748.

Elsby, M., R. Michaels and G. Solon, (2009), The Ins and Outs of Cyclical Unemployment, American Economic Journal: Macroeconomics, 1(1): 84-110

Eriksson S. and Lagerström, J. (2006). Competition between Employed and Unemployed Job Applicants: Swedish Evidence. Scandinavian Journal of Economics, 108(3): 373-396.

Ferragina, A.M. and Pastore, F. (2008). Mind the Gap: Unemployment in the New EU Regions. Journal of Economic Surveys, 22(1): 73-113.

Fortin, M. and Araar, A. (1997). Sectoral Shifts, Stock Market Dispersion and Unemployment in Canada. Applied Economics, 29(6): 829-839.

Fujita S. and G. Ramey (2009), The Cyclicality of Separation and Job Finding Rates, International Economic Review, 50(2): 415-430

Funck, B. and Pizzati, L. (2002, Eds.). Labour, Employment and Social Policy in the EU Enlargement Process. Changing Perspectives and Policy Options. Washington, D.C.: World Bank.

Funck, B. and Pizzati, L. (2003, Eds.). European Integration, Regional Policy and Growth, Washington, D.C.: World Bank.

Garonna, P. and Sica, F. (2000). Intersectoral Labour Reallocations and Unemployment in Italy. Labour Economics, 7(6): 711-728.

Góra, M. and H. Lehmann (1995), “How Divergent is Regional Labour Market Adjustment in Poland?”, Scarpetta, S. and A. Wörgötter (eds.), cit.

Gorzelak, G. (1996), The Regional Dimension of Transformation in Central Europe, Jessica Kingsley Publishers, London.

Hall, R. (2005), Employment Efficiency and Sticky Wages: Evidence form Flows in the Labor Market, Review of Economics and Statistics, 87(3): 397-407

Holzer, H.J. (1991). Employment, Unemployment and Demand Shifts in Local Labour Markets. Review of Economics and Statistics, 73(1): 25-32.

Hyclak, T. (1996). Structural Changes in Labour Demand and Unemployment in Local Labour Markets. Journal of Regional Science, 36(4): 653-663.

Krajnyàk, K. and Sommer, M. (2004). Czech Republic, IMF country Report, n. 4/265, August.

Krugman P. (1994), "Past and Prospective Causes of High Unemployment”, Economic Review, Federal Reserve Bank of Kansas City, pp. 23-43.

Layard, R., Nickell, S. and Jackman, R (1991). Unemployment. Macroeconomic performance and the labour market.Oxford: Oxford University Press.

Lehmann, H. and Walsh, P. P. (1999). Gradual Restructuring and Structural Unemployment in Poland: A Legacy of Central Planning. LICOS DP, n. 78, Katholieke Universiteit Leuven.

Lilien, D. M. (1982). Sectoral Shifts and Cyclical Unemployment. Journal of Political Economy, 90(4): 777-793.

Naticchioni, P., Rustichelli, E. and Scialà, A. (2006). Employment Protection and Regional Labour Market Flows. Economia Politica, 23(3): 453-474.

Neelin, J. (1987). Sectoral Shifts and Canadian Unemployment. Review of Economics and Statistics, 69(4): 718723.

Neumann, G. R. and Topel, R.H. (1991). Employment Risk, Diversification, and Unemployment. Quarterly Journal of Economics, 106(4): 1341-1365. 
Newell, A. and Pastore, F. (2006). Regional Unemployment and Industrial Restructuring in Poland. Eastern European Economics, 44(3): 5-28.

Nickell, S. 1981. Biases in dynamic models with fixed effects. Econometrica 49(6): 1417-26.

Pastore, F. and M. Socha (2006), The Polish LFS: A Rotating Panel with Attrition, Ekonomia, 15(3): 3-24.

Petrongolo, B. and Ch. Pissarides, (2008), The Ins and the Outs of European Unemployment, American Economic Review, 98(2): 256-262

Robson, M. (2001). Regional Variations in the Competitiveness of Unemployed Job-Seekers and the Rate of Outflows from Unemployment. Oxford Bulletin of Economics and Statistics, 63(1): 61-90.

Robson, M. (2009). Structural Change, Specialization and Regional Labour Market Performance: Evidence for the UK. Applied Economics, 41(3): 275-293.

Rutkowski, J. (2003). Rapid Labour Reallocation with a Stagnant Unemployment Pool: The Puzzle of the Labour Market in Lithuania. World Bank, Policy Research working paper series, n. 2946.

Rutkowski, J. and Przybila, M. (2002). Poland: Regional Dimensions of Unemployment. In B. Funck and L. Pizzati (eds.), op. cit., (pp. 157-175).

Samson, L. (1985). A Study of Impact of Sectoral Shifts on Aggregate Unemployment in Canada. Canadian Journal of Economics, 18(3): 518-530.

Scarpetta, S. and P. Huber (1995), "Regional Economic Structures and Unemployment in Central and Eastern Europe. An Attempt to Identify Common Patterns”, in Scarpetta, S. and A. Wörgötter (op. cit.)

Scarpetta, S. and A. Wörgötter (1995, eds.), “The Regional Dimension of Unemployment in Transition Countries. A Challenge for Labour Market and Social Policies”, OECD-CCET, Paris.

Shimer, R. (2007), "Reassessing the Ins and Outs of Unemployment", NBER Working Papers, N 13421.

Simon, C. J. (1988). Frictional Unemployment and the Role of Industrial Diversity. Quarterly Journal of Economics, 103(4): 715-728.

Simon, C. J. and Nardinelli, C. (1992). Does Unemployment Diversity always Reduce unemployment? Evidence from the Great Depression and After. Economic Enquiry, 30(2): 384-397.

Strawiński, P. (2009), Ins and Outs of Polish Unemployment, Central European Journal of Economic Modelling and Econometrics, 1(3): 243-259.

Tyrowicz J. and Wójcik, P., (2010a), Regional Dynamics of Unemployment. A Convergence Approach, in: F. E. Caroleo and F. Pastore (eds.) The Labour Market Impact of the EU Enlargement. A New Regional Geography of Europe? Physica Verlag, Heidelberg.

Tyrowicz, J. and Wójcik, P, (2011), Nonlinear Stochastic Convergence Analysis of Regional Unemployment Rates in Poland, Review of Economic Analysis, forthcoming

Van Ours, J.C. (1995). An Empirical Note on Employed and Unemployed Job Search. Economics Letters, 49(4): 447-452.

Walsh, P. P. (2003). The Cyclical Pattern of Regional Unemployment Flows in Poland. Economic Systems, 27(2): 155-169.

World Bank (2001). Poland-Labor Market Study: The Challenge of Job Creation. World Bank Country Study, March. 
Appendix of Tables and Figures

Table 1.Inflow and outflow components of the turnover

\begin{tabular}{l|lll}
\hline \multirow{2}{*}{ Flow } & \multicolumn{3}{c}{ Share in } \\
\cline { 2 - 4 } & inflows & outlows & turnover \\
\hline Administrative de-listing (AD) & & 0.411 & 0.119 \\
Job finding (JF) & & 0.527 & 0.152 \\
Re-registration (RR) & 0.806 & & 0.573 \\
First-time registration (FT) & 0.194 & & 0.138 \\
Activisation schemes (AS) & & 0.063 & 0.018 \\
\hline
\end{tabular}

Source: Own elaboration on ML\&SA data.

Table 2. The Lilien Index by stratification group

\begin{tabular}{l|cccc}
\multicolumn{1}{c|}{ Group } & Mean & Max & Min & \% of poviats above mean of total sample \\
\hline Total sample & .055 & .286 & .002 & - \\
Laggards & .062 & .099 & .022 & $27 \%$ \\
Transition & .068 & .240 & .013 & $41 \%$ \\
Industrial & .078 & .197 & .009 & $67 \%$ \\
\hline \multicolumn{5}{l}{ Source: Own elaboration on ML\&SA and CSO data. T-test for the equality of means reported, *** denote statistical significance at 1\% level. }
\end{tabular}


Table 3. Descriptive statistics by group of poviat

\begin{tabular}{|c|c|c|c|c|}
\hline Variable & Full sample & Laggards & Transition & Industrial \\
\hline $\begin{array}{l}\text { Unemployed registering } \\
\text { (flow) }\end{array}$ & $\begin{array}{c}566.68 \\
{[422.4129]}\end{array}$ & $\begin{array}{c}394.69 \\
{[269.7165]}\end{array}$ & $\begin{array}{l}379.90 \\
{[229.1238]}\end{array}$ & $\begin{array}{c}862.22 \\
{[661.5636]}\end{array}$ \\
\hline $\begin{array}{l}\text { Unemployed who got employed this month - JF } \\
\text { (flow) }\end{array}$ & $\begin{array}{l}268.74 \\
{[210.3583]}\end{array}$ & $\begin{array}{l}181.59 \\
{[141.8534]}\end{array}$ & $\begin{array}{l}176.28 \\
{[123.2595]}\end{array}$ & $\begin{array}{l}375.77 \\
{[321.1451]}\end{array}$ \\
\hline $\begin{array}{l}\text { No of unemployed } \\
\text { (stock) }\end{array}$ & $\begin{array}{c}6922.39 \\
{[5227.872]}\end{array}$ & $\begin{array}{c}5684.82 \\
{[3834.46]}\end{array}$ & $\begin{array}{l}5405.76 \\
{[3277.776]}\end{array}$ & $\begin{array}{c}9763.32 \\
{[8229.325]}\end{array}$ \\
\hline $\begin{array}{l}\text { No of unemployed, previously registered - RR } \\
\text { (flow) }\end{array}$ & $\begin{array}{l}416.61 \\
{[293.3067]}\end{array}$ & $\begin{array}{l}296.33 \\
{[214.3105]}\end{array}$ & $\begin{array}{l}283.90 \\
{[183.5827]}\end{array}$ & $\begin{array}{l}614.86 \\
{[434.9242]}\end{array}$ \\
\hline $\begin{array}{l}\text { No of delisted unemployed - AD } \\
\text { (flow) }\end{array}$ & $\begin{array}{l}192.20 \\
{[179.4544]}\end{array}$ & $\begin{array}{l}127.15 \\
{[97.5701]}\end{array}$ & $\begin{array}{c}125.61 \\
{[89.2682]}\end{array}$ & $\begin{array}{l}328.05 \\
{[268.931]}\end{array}$ \\
\hline $\begin{array}{l}\text { No of unemployed, first time registered - FT } \\
\text { (flow) }\end{array}$ & $\begin{array}{c}150.07 \\
{[168.9209]}\end{array}$ & $\begin{array}{l}98.36 \\
{[77.7356]}\end{array}$ & $\begin{array}{l}96.00 \\
{[68.6223]}\end{array}$ & $\begin{array}{c}247.37 \\
{[275.4883]}\end{array}$ \\
\hline $\begin{array}{l}\text { No of unemployed, in activisation schemes - AS } \\
\text { (flow) }\end{array}$ & $\begin{array}{c}102.08 \\
{[104.6981]}\end{array}$ & $\begin{array}{l}80.40 \\
{[78.3089]}\end{array}$ & $\begin{array}{l}78.10 \\
{[71.6473]}\end{array}$ & $\begin{array}{c}134.16 \\
{[147.5468]}\end{array}$ \\
\hline $\begin{array}{l}\text { Labour force [computed] } \\
\text { (stock) }\end{array}$ & $\begin{array}{l}43218 \\
{[58286.38]}\end{array}$ & $\begin{array}{c}33797 \\
{[18196.74]}\end{array}$ & $\begin{array}{c}32941 \\
{[15952.96]}\end{array}$ & $\begin{array}{c}73396 \\
{[71876.52]}\end{array}$ \\
\hline $\begin{array}{l}\text { Service share in employment } \\
\text { (stock, \% of working population) }\end{array}$ & $\begin{array}{c}0.403 \\
{[.1459]}\end{array}$ & $\begin{array}{c}0.220 \\
{[.0413]}\end{array}$ & $\begin{array}{c}0.229 \\
{[.0395]}\end{array}$ & $\begin{array}{c}0.586 \\
{[.1328]}\end{array}$ \\
\hline $\begin{array}{l}\text { Fixed capital formation per capita } \\
\text { (standardised) }\end{array}$ & $\begin{array}{l}-0.000 \\
{[.9992]}\end{array}$ & $\begin{array}{l}-0.642 \\
{[.0702]}\end{array}$ & $\begin{array}{l}-0.463 \\
{[.4442]}\end{array}$ & $\begin{array}{c}0.589 \\
{[1.243]}\end{array}$ \\
\hline $\begin{array}{l}\text { Per capita tax revenues } \\
\text { (standardised) }\end{array}$ & $\begin{array}{l}-0.000 \\
{[.9992]}\end{array}$ & $\begin{array}{l}-0.879 \\
{[0.2641]}\end{array}$ & $\begin{array}{l}-0.743 \\
{[0.3681]}\end{array}$ & $\begin{array}{l}1.376 \\
{[0.7718]}\end{array}$ \\
\hline Unemployment rate [\%] & $\begin{array}{c}18.66 \\
{[7.5397]}\end{array}$ & $\begin{array}{c}16.60 \\
{[5.424]}\end{array}$ & $\begin{array}{l}16.49 \\
{[5.4607]}\end{array}$ & $\begin{array}{c}15.49 \\
{[6.068]}\end{array}$ \\
\hline Adjusted unemployment rate [\%] & $\begin{array}{r}18.26 \\
{[7.51]}\end{array}$ & $\begin{array}{r}16.29 \\
{[5.41]}\end{array}$ & $\begin{array}{r}16.17 \\
{[5.43]}\end{array}$ & $\begin{array}{r}15.05 \\
{[6.04]}\end{array}$ \\
\hline Inflows (FT+RR/LF) [\%] & $\begin{array}{c}1.540 \\
{[.0069]}\end{array}$ & $\begin{array}{c}1.180 \\
{[.0048]}\end{array}$ & $\begin{array}{c}1.190 \\
{[.0048]}\end{array}$ & $\begin{array}{r}1.380 \\
{[.005]}\end{array}$ \\
\hline Outflows (JF+AS+AD/LF) [\%] & $\begin{array}{c}1.560 \\
{[.0083]}\end{array}$ & $\begin{array}{c}1.180 \\
{[.0059]}\end{array}$ & $\begin{array}{r}1.210 \\
{[.006]}\end{array}$ & $\begin{array}{c}1.350 \\
{[.0058]}\end{array}$ \\
\hline Turnover (inflows + outflows) [\%] & $\begin{array}{c}3.100 \\
{[.0138]}\end{array}$ & $\begin{array}{c}2.360 \\
{[.0093]}\end{array}$ & $\begin{array}{c}2.390 \\
{[.0095]}\end{array}$ & $\begin{array}{c}2.730 \\
{[.0099]}\end{array}$ \\
\hline Adjusted outflows (JF/LF) [\%] & $\begin{array}{c}1.060 \\
{[.0065]}\end{array}$ & $\begin{array}{c}0.810 \\
{[.0048]}\end{array}$ & $\begin{array}{c}0.820 \\
{[.0048]}\end{array}$ & $\begin{array}{c}0.830 \\
{[.0041]}\end{array}$ \\
\hline Adjusted inflows (FT/LF) [\%] & $\begin{array}{c}0.380 \\
{[.0019]}\end{array}$ & $\begin{array}{c}0.290 \\
{[.0014]}\end{array}$ & $\begin{array}{c}0.300 \\
{[.0014]}\end{array}$ & $\begin{array}{c}0.360 \\
{[.0017]}\end{array}$ \\
\hline $\begin{array}{l}\text { Adjusted turnover } \\
\text { (adjusted inflows + adjusted outflows) [\%] }\end{array}$ & $\begin{array}{c}1.440 \\
{[.0072]}\end{array}$ & $\begin{array}{c}1.100 \\
{[.0052]}\end{array}$ & $\begin{array}{c}1.120 \\
{[.0053]}\end{array}$ & $\begin{array}{c}1.200 \\
{[.0046]}\end{array}$ \\
\hline Number of observations & 40202 & 4663 & 7843 & 6993 \\
\hline
\end{tabular}

- Notes: Standard deviations in brackets. Each observation is an average computed on the entire sample period.

Source: Own elaboration on ML\&SA and CSO data. 
Table 4. Estimations results, unemployment rate (raw and adjusted) as determined variable

\begin{tabular}{|c|c|c|c|c|c|c|c|c|c|c|c|c|c|c|}
\hline \multirow[b]{2}{*}{ Variable } & \multicolumn{7}{|c|}{ Raw data } & \multicolumn{7}{|c|}{ Adjusted data } \\
\hline & {$[1]$} & {$[2]$} & [3] & [4] & [5] & [6] & [7] & [8] & [9] & {$[10]$} & [11] & [12] & [13] & [14] \\
\hline Turnover & $\begin{array}{r}0.8479 * * * \\
{[0.003]}\end{array}$ & & & $\begin{array}{r}0.7723^{* * *} * \\
{[0.004]}\end{array}$ & & & & $\begin{array}{r}0.7515^{* * * *} \\
(0.004)\end{array}$ & & & $\begin{array}{r}0.6381^{* * *} \\
(0.004)\end{array}$ & & & \\
\hline Inflows & & $\begin{array}{r}0.5926^{* * * *} \\
{[0.005]}\end{array}$ & & & $\begin{array}{r}0.5628^{* * *} * \\
{[0.005]}\end{array}$ & & & & $\begin{array}{r}0.1230^{* * * *} \\
(0.004)\end{array}$ & & & $\begin{array}{r}0.1950^{* * * *} \\
(0.005)\end{array}$ & & \\
\hline Outflows & & $\begin{array}{r}0.2676^{* * * *} \\
{[0.005]} \\
\end{array}$ & & & $\begin{array}{r}0.2301 * * * \\
{[0.005]} \\
\end{array}$ & & & & $\begin{array}{r}0.5994^{* * *} \\
(0.003) \\
\end{array}$ & & & $\begin{array}{r}0.4677^{* * * *} \\
(0.003) \\
\end{array}$ & & \\
\hline $\mathrm{AD}$ & & & $\begin{array}{r}-0.1146 * * * \\
{[0.004]}\end{array}$ & & & $\begin{array}{r}-0.0713 * * * \\
{[0.003]}\end{array}$ & & & & & & & & \\
\hline $\mathrm{JF}$ & & & $\begin{array}{r}0.1672^{* * *} \\
{[0.006]}\end{array}$ & & & $\begin{array}{r}0.1247 * * * \\
{[0.006]}\end{array}$ & & & & $\begin{array}{r}0.1819^{* * * *} \\
(0.006)\end{array}$ & & & $\begin{array}{r}0.1305^{* * *} \\
(0.006)\end{array}$ & \\
\hline FT & & & $\begin{array}{r}-0.4208 * * * * \\
{[0.005]}\end{array}$ & & & $\begin{array}{r}-0.2771 * * * \\
{[0.005]}\end{array}$ & & & & $\begin{array}{r}-0.4756 * * * \\
(0.005)\end{array}$ & & & $\begin{array}{r}-0.2992 * * * \\
(0.005)\end{array}$ & \\
\hline $\mathrm{RR}$ & & & $\begin{array}{r}0.3898^{* * *} \\
{[0.007]} \\
0.0201 * * * \\
{[0.002]} \\
\end{array}$ & & & $\begin{array}{r}0.3514^{* * *} * \\
{[0.007]} \\
0.0114^{* * *} \\
{[0.002]} \\
\end{array}$ & & & & & & & & \\
\hline Institutional turnover & & & & & & & $\begin{array}{r}0.4949 * * * \\
{[0.004]}\end{array}$ & & & & & & & $\begin{array}{l}0.0733 \\
(0.086)\end{array}$ \\
\hline Market turnover & & & & & & & $\begin{array}{r}0.2756 * * * \\
{[0.003]} \\
\end{array}$ & & & & & & & $\begin{array}{r}0.7147^{* * *} \\
(0.078) \\
\end{array}$ \\
\hline Tax revenues & & & & $\begin{array}{r}-0.0837 * * * \\
{[0.001]}\end{array}$ & $\begin{array}{r}-0.0855 * * * \\
{[0.001]}\end{array}$ & $\begin{array}{r}-0.0635 * * * \\
{[0.003]}\end{array}$ & $\begin{array}{r}-0.1011^{* * *} \\
{[0.001]}\end{array}$ & & & & $\begin{array}{r}-0.1145^{* * *} \\
(0.002)\end{array}$ & $\begin{array}{r}-0.1115^{* * * *} \\
(0.002)\end{array}$ & $\begin{array}{r}-0.0736^{* * *} \\
(0.003)\end{array}$ & $\begin{array}{r}-0.8085^{*} \\
(0.478)\end{array}$ \\
\hline Investment & & & & $\begin{array}{r}-0.0141 * * * \\
{[0.001]}\end{array}$ & $\begin{array}{r}-0.0140^{* * * *} \\
{[0.001]}\end{array}$ & $\begin{array}{r}-0.0440^{* * *} \\
{[0.002]}\end{array}$ & $\begin{array}{r}-0.0117^{* * *} \\
{[0.001]}\end{array}$ & & & & $\begin{array}{r}-0.0193 * * * \\
(0.002)\end{array}$ & $\begin{array}{r}-0.0188^{* * *} \\
(0.002)\end{array}$ & $\begin{array}{r}-0.0450 * * * \\
(0.002)\end{array}$ & $\begin{array}{c}-26.8408 \\
(31.701)\end{array}$ \\
\hline Services & & & & $\begin{array}{r}0.3008^{* * *} \\
{[0.015]} \\
\end{array}$ & $\begin{array}{r}0.2569 * * * \\
{[0.015]} \\
\end{array}$ & $\begin{array}{r}1.1368 * * * \\
{[0.023]} \\
\end{array}$ & $\begin{array}{r}0.3165^{* * *} \\
{[0.015]}\end{array}$ & & & & $\begin{array}{r}0.6840^{* * *} \\
(0.019) \\
\end{array}$ & $\begin{array}{r}0.6477^{* * * *} \\
(0.019) \\
\end{array}$ & $\begin{array}{r}1.1492 * * * \\
(0.023) \\
\end{array}$ & $\begin{array}{c}-92.5368 \\
(264.730) \\
\end{array}$ \\
\hline Constant & $1.2550^{* * * *}$ & $1.9069 * * *$ & $-2.4741^{* * *}$ & $0.9069 * * *$ & $1.5569 * * *$ & $\begin{array}{l}-3.2346^{* * * *} \\
\end{array}$ & $1.3374 * * *$ & $1.4799 * * *$ & $\begin{array}{r}1.7362 * * * \\
(0.022)\end{array}$ & $\begin{array}{r}-2.4580 * * * \\
(0.022)\end{array}$ & $0.7698^{* * *}$ & $1.3206 * * *$ & $-3.2827 * * *$ & $\begin{array}{r}30.3561 \\
(89.797)\end{array}$ \\
\hline Number of observations & $\begin{array}{l}0.011) \\
39,838\end{array}$ & $\frac{(0.014)}{39,838}$ & $\begin{array}{l}(0.921) \\
39,185\end{array}$ & $\begin{array}{l}0.0230 \\
33,090\end{array}$ & $\frac{[0.025]}{33,090}$ & $\begin{array}{r}0.027] \\
32,527\end{array}$ & \begin{tabular}{|c|}
{$[0.018]$} \\
33,090
\end{tabular} & $\frac{(0.016)}{39,838}$ & $\frac{(0.022)}{39,838}$ & $\frac{(0.022)}{39,838}$ & $\frac{(0.028)}{33,090}$ & $\frac{(0.034)}{33,090}$ & $\frac{(0.029)}{33,090}$ & $\mid \frac{(89.797)}{33,090}$ \\
\hline R2 within & 0.684 & 0.688 & 0.294 & 0.716 & 0.726 & 0.425 & 0.721 & 0.567 & 0.593 & 0.271 & 0.605 & 0.619 & 0.414 & 0.493 \\
\hline
\end{tabular}

Note: Monthly data, annual and monthly dummies included. Time fixed effect panel GLS estimator with robust standard errors. Tax data only available for land poviats, 
Table 5. Estimation results, unemployment rate as a determined variable, monthly data

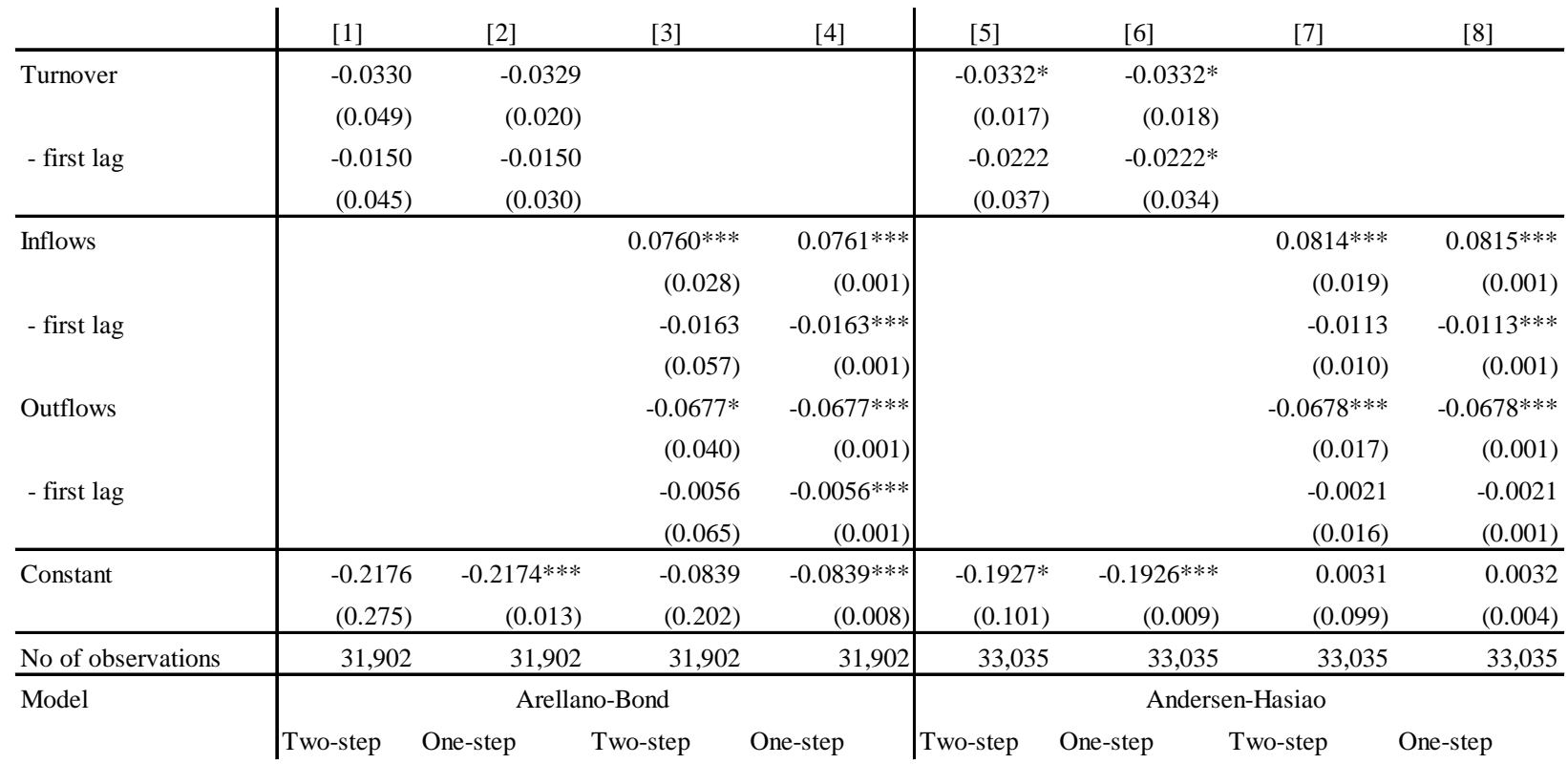

Note: Each estimation includes up to 6 lags for unemployment and up to 4 lags for independent variables, (computational constraints prohibited including further lags). In addition, Andersen-Hsiao estimators also include lagged second differences of dependent and independent variables as instruments. Robust standard errors. Statistics for Sargan test and identification test computed robustness correction (as only possible in Stata11). Lags of unemployment significant, not-reported, available upon request. 
Table 6. Spatial regressions, unemployment rate as determined variable, spatial lag model with weights based on adjacency.

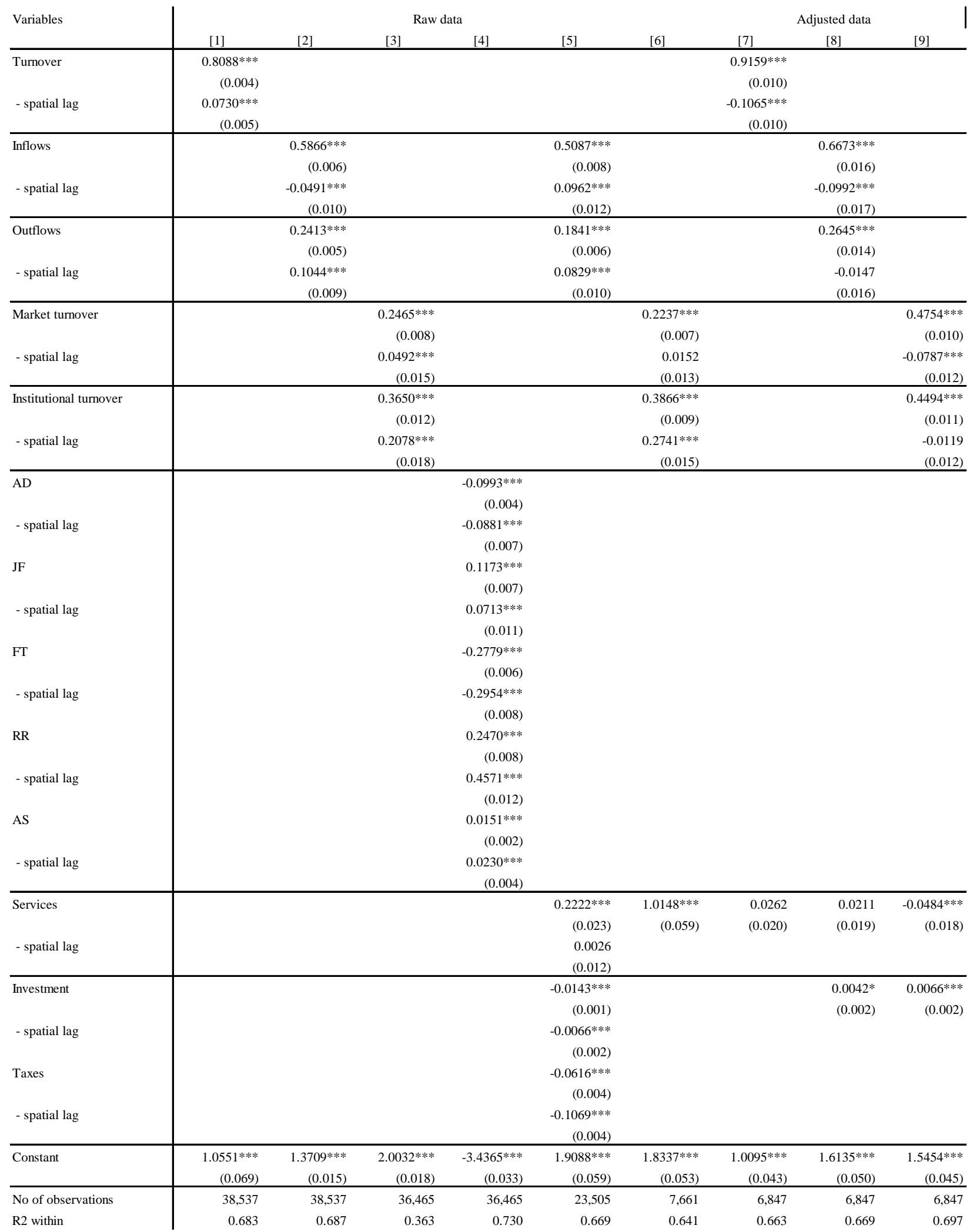


Table 7a. Estimation results, stratification, unemployment rate as determined variable

\begin{tabular}{|c|c|c|c|c|c|c|c|c|c|}
\hline \multirow[t]{2}{*}{ Variables } & \multicolumn{3}{|c|}{ Laggards } & \multicolumn{3}{|c|}{ Transition } & \multicolumn{3}{|c|}{ Industrial } \\
\hline & [1] & [2] & [3] & [4] & [5] & [6] & [7] & [8] & [9] \\
\hline Turnover & $\begin{array}{l}0.7433^{\star \star \star} \\
(0.009)\end{array}$ & & & $\begin{array}{l}0.7622^{\star \star \star} \\
(0.007)\end{array}$ & & & $\begin{array}{l}0.8809^{\star \star \star} \\
(0.009)\end{array}$ & & \\
\hline $\begin{array}{l}\text { Inflows } \\
\text { Outflows }\end{array}$ & & $\begin{array}{l}0.5760^{\star \star \star} \\
(0.012) \\
0.1962^{\star \star \star} \\
(0.011)\end{array}$ & & & $\begin{array}{l}0.5886^{\star \star \star} \\
(0.010) \\
0.2079^{\star \star \star} \\
(0.009) \\
\end{array}$ & & & $\begin{array}{l}0.6283^{\star \star \star} \\
(0.014) \\
0.2658^{\star \star \star} \\
(0.013) \\
\end{array}$ & \\
\hline $\begin{array}{l}\text { Market turnover } \\
\text { Institutional turnover }\end{array}$ & & & $\begin{array}{l}0.2364^{\star \star \star} \\
(0.007) \\
0.4669^{\star \star \star} \\
(0.009) \\
\end{array}$ & & & $\begin{array}{l}0.2202^{\star \star \star} \\
(0.006) \\
0.4878^{\star \star \star} \\
(0.008)\end{array}$ & & & $\begin{array}{l}0.4407^{\star \star \star} \\
(0.009) \\
0.4576^{\star \star \star} \\
(0.008)\end{array}$ \\
\hline Services & $\begin{array}{l}0.8107^{\star \star *} \\
(0.078)\end{array}$ & $\begin{array}{l}0.7560^{\star \star \star} \\
(0.076)\end{array}$ & $\begin{array}{l}1.1806^{\star \star *} \\
(0.075)\end{array}$ & $\begin{array}{l}0.5065^{\star \star *} \\
(0.061)\end{array}$ & $\begin{array}{l}0.4557^{\star \star \star} \\
(0.060)\end{array}$ & $\begin{array}{l}0.8006^{\star * *} \\
(0.059)\end{array}$ & $\begin{array}{l}-0.0242 \\
(0.019)\end{array}$ & $\begin{array}{l}-0.0291 \\
(0.019)\end{array}$ & $\begin{array}{l}-0.0754^{\text {*** }} \\
(0.018)\end{array}$ \\
\hline Investment & $\begin{array}{l}-0.2177^{\star \star \star} \\
(0.043)\end{array}$ & $\begin{array}{l}-0.1884^{\star \star \star} \\
(0.042) \\
\end{array}$ & $\begin{array}{l}-0.3046^{\star \star \star} \\
(0.039) \\
\end{array}$ & $\begin{array}{l}-0.0581^{\star \star \star} \\
(0.006)\end{array}$ & $\begin{array}{l}-0.0533^{\star * *} \\
(0.005)\end{array}$ & $\begin{array}{l}-0.0543^{\star * *} \\
(0.007)\end{array}$ & \begin{tabular}{|l}
$-0.0063^{\star \star \star}$ \\
$(0.002)$ \\
\end{tabular} & $\begin{array}{l}-0.0052^{\star \star} \\
(0.002) \\
\end{array}$ & $\begin{array}{l}0.0002 \\
(0.002) \\
\end{array}$ \\
\hline Constant & $\begin{array}{l}0.6728^{\star \star \star} \\
(0.048)\end{array}$ & $\begin{array}{l}1.3625^{\star * *} \\
(0.051)\end{array}$ & $\begin{array}{l}0.8005^{\star * *} \\
(0.044)\end{array}$ & $\begin{array}{l}0.9000^{* * *} \\
(0.036)\end{array}$ & $\begin{array}{l}1.6113^{* * *} \\
(0.040)\end{array}$ & $\begin{array}{l}1.0523^{\star * *} \\
(0.035)\end{array}$ & $\begin{array}{l}1.2955^{\star \star \star} \\
(0.040)\end{array}$ & $\begin{array}{l}1.9693^{* * *} \\
(0.045)\end{array}$ & $\begin{array}{l}1.8191^{* * *} \\
(0.035)\end{array}$ \\
\hline $\begin{array}{l}\text { No of observations } \\
\text { R2 within }\end{array}$ & 0.625 & $\begin{array}{ll}3 & 466 \\
0.651 & \end{array}$ & $\begin{array}{ll}3 & 4663 \\
0.644 & \end{array}$ & $\mid \begin{array}{ll} & 784 \\
0.623 & \end{array}$ & $\begin{array}{ll}3 & 7843 \\
0.646 & \end{array}$ & 0.609 & 0.664 & $0.670^{6969}$ & $\begin{array}{ll}6969 \\
0.696\end{array}$ \\
\hline
\end{tabular}




\begin{tabular}{|c|c|c|c|c|c|c|c|c|c|}
\hline \multirow[t]{2}{*}{ Variables } & \multicolumn{3}{|c|}{ Laggards } & \multicolumn{3}{|c|}{ Transition } & \multicolumn{3}{|c|}{ Industrial } \\
\hline & [1] & [2] & [3] & [4] & [5] & [6] & [7] & [8] & [9] \\
\hline Turnover & $\begin{array}{r}0.7433 * * * \\
(0.009) \\
\end{array}$ & & & $\begin{array}{r}0.7622 * * * \\
(0.007) \\
\end{array}$ & & & $\begin{array}{r}0.8809^{* * *} \\
(0.009) \\
\end{array}$ & & \\
\hline Inflows & & $\begin{array}{r}0.5760^{* * *} \\
(0.012)\end{array}$ & & & $\begin{array}{r}0.5886 * * * \\
(0.010)\end{array}$ & & & $\begin{array}{r}0.6283^{* * *} \\
(0.014)\end{array}$ & \\
\hline Outflows & & $\begin{array}{r}0.1962^{* * *} \\
(0.011) \\
\end{array}$ & & & $\begin{array}{r}0.2079 * * * \\
(0.009) \\
\end{array}$ & & & $\begin{array}{r}0.2658 * * * \\
(0.013) \\
\end{array}$ & \\
\hline Market turnover & & & $\begin{array}{r}0.2364 * * * \\
(0.007)\end{array}$ & & & $\begin{array}{r}0.2202^{* * *} \\
(0.006)\end{array}$ & & & $\begin{array}{r}0.4407^{* * *} \\
(0.009)\end{array}$ \\
\hline Institutional turnover & & & $\begin{array}{r}0.4669 * * * \\
(0.009) \\
\end{array}$ & & & $\begin{array}{r}0.4878^{* * *} \\
(0.008) \\
\end{array}$ & & & $\begin{array}{r}0.4576^{* * *} \\
(0.008) \\
\end{array}$ \\
\hline Services & $\begin{array}{r}0.8107 * * * \\
(0.078)\end{array}$ & $\begin{array}{r}0.7560^{* * *} \\
(0.076)\end{array}$ & $\begin{array}{r}1.1806 * * * \\
(0.075)\end{array}$ & $\begin{array}{r}0.5065^{* * *} \\
(0.061)\end{array}$ & $\begin{array}{r}0.4557^{* * *} \\
(0.060)\end{array}$ & $\begin{array}{r}0.8006^{* * * *} \\
(0.059)\end{array}$ & $\begin{array}{l}-0.0242 \\
(0.019)\end{array}$ & $\begin{array}{l}-0.0291 \\
(0.019)\end{array}$ & $\begin{array}{r}-0.0754^{* * *} \\
(0.018)\end{array}$ \\
\hline Investment & $\begin{array}{r}-0.2177^{* * *} \\
(0.043) \\
\end{array}$ & $\begin{array}{r}-0.1884^{* * * *} \\
(0.042) \\
\end{array}$ & $\begin{array}{r}-0.3046^{* * *} \\
(0.039) \\
\end{array}$ & $\begin{array}{r}-0.0581^{* * *} \\
(0.006) \\
\end{array}$ & $\begin{array}{r}-0.0533^{* * *} \\
(0.005) \\
\end{array}$ & $\begin{array}{r}-0.0543^{* * *} \\
(0.007) \\
\end{array}$ & $\begin{array}{r}-0.0063^{* * *} \\
(0.002) \\
\end{array}$ & $\begin{array}{r}-0.0052^{* *} \\
(0.002) \\
\end{array}$ & $\begin{array}{r}0.0002 \\
(0.002) \\
\end{array}$ \\
\hline Constant & $\begin{array}{r}0.6728^{* * *} \\
(0.048) \\
\end{array}$ & $\begin{array}{r}1.3625^{* * *} \\
(0.051) \\
\end{array}$ & $\begin{array}{r}0.8005^{* * *} \\
(0.044) \\
\end{array}$ & $\begin{array}{r}0.9000^{* * *} \\
(0.036) \\
\end{array}$ & $\begin{array}{r}1.6113^{* * *} \\
(0.040) \\
\end{array}$ & $\begin{array}{r}1.0523 * * * \\
(0.035) \\
\end{array}$ & $\begin{array}{r}1.2955^{* * *} \\
(0.040) \\
\end{array}$ & $\begin{array}{r}1.9693 * * * \\
(0.045) \\
\end{array}$ & $\begin{array}{r}1.8191^{* * *} \\
(0.035) \\
\end{array}$ \\
\hline No of observations & 4663 & 4663 & 4663 & 7843 & 7843 & 7843 & 6969 & 6969 & 6969 \\
\hline R2 within & 0.625 & 0.651 & 0.644 & 0.623 & 0.646 & 0.609 & 0.664 & 0.670 & 0.696 \\
\hline
\end{tabular}


Table 7b. Estimation results, stratification, unemployment rate as determined variable with spatial correction



Note: Time fixed effect panel GLS estimator with robust standard errors. 
Figure 1. Unemployment rate evolution in Poland, 1990-2009.

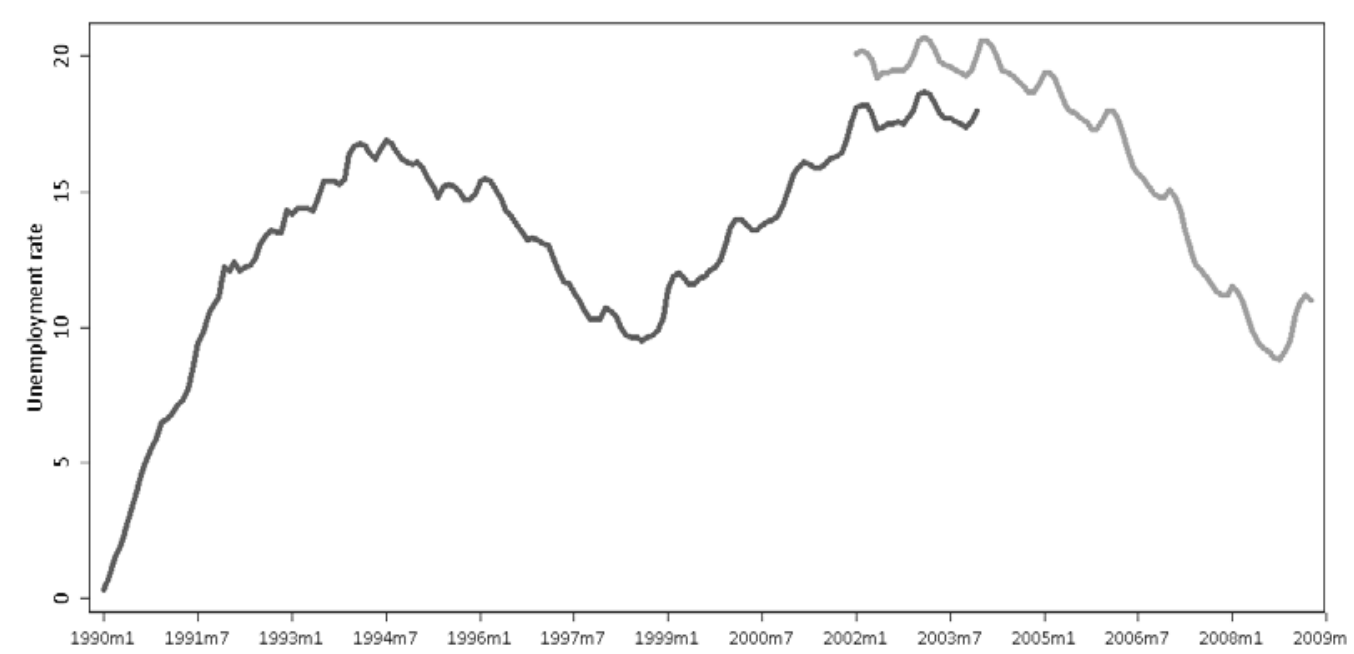

Source: CSO

Note: In January 2004, new census data have yielded a lower size of the population and thus higher unemployment rate (by roughly 3.2 percentage points). In panel estimations time effect is removed so this adjustment plays no role in the estimations. In the GMM estimations additional control variable is introduced.

Figure 2. The regional distribution of the unemployment rates in Poland (averaged over 2000-2008)

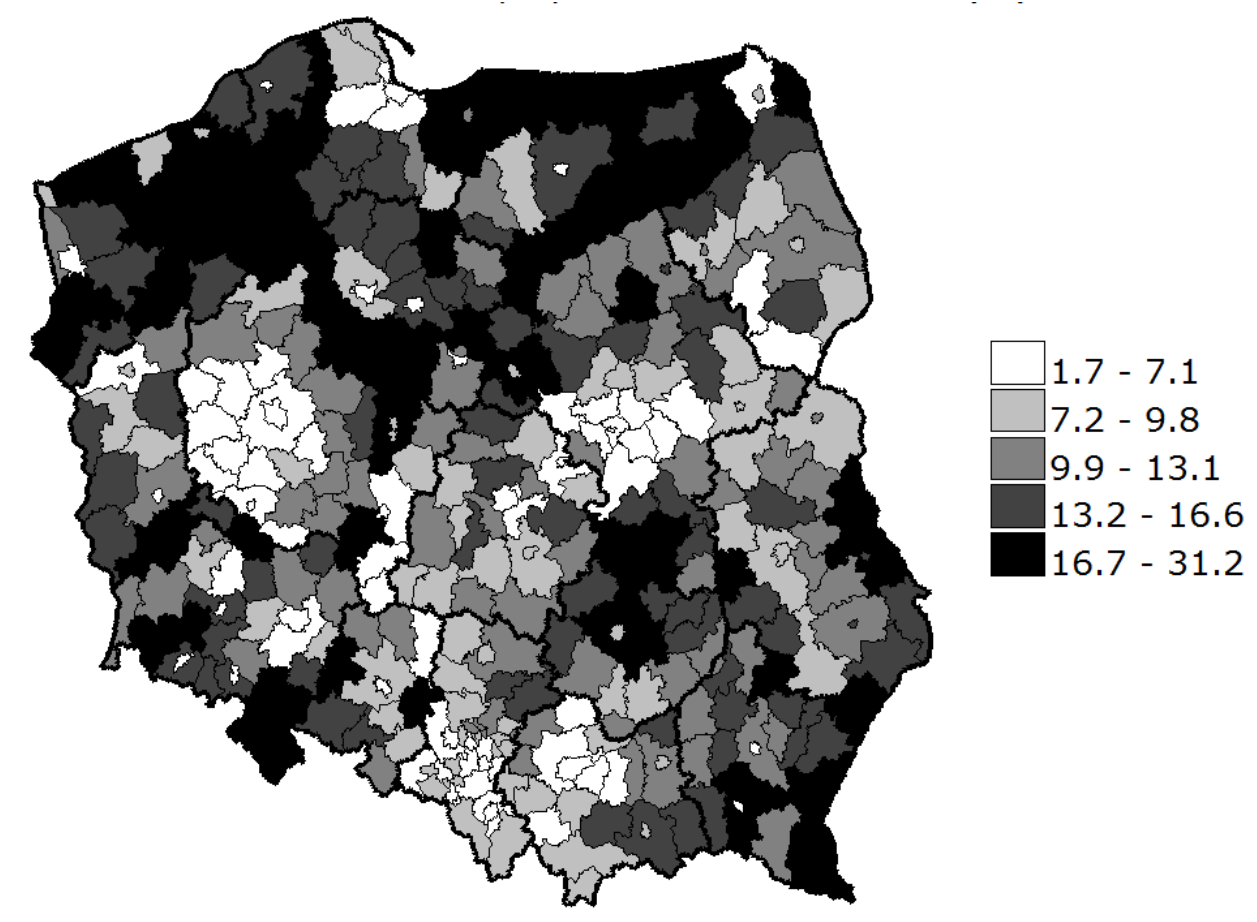

Source: CSO

Note: The darker the shade, the higher the unemployment rate in percent. 
Figure 3. Scatter of monthly inflow and outflow rates by year and voivodship Panel (a)


Outflows (all de-registrations)
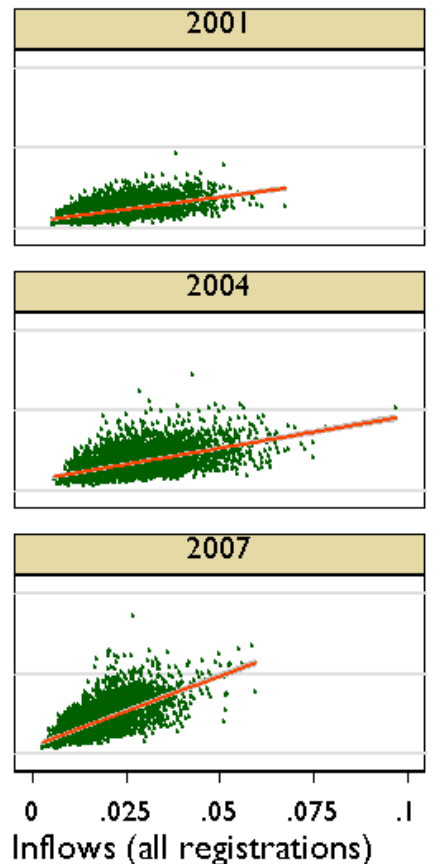

$95 \% \mathrm{Cl}$


Fitted values

\section{Panel (b)}


- Outflows (all de-registrations)

$95 \% \mathrm{Cl}$

Fitted values 
Figure 4. Unemployment, inflow and outflow rates by region (voivodship)
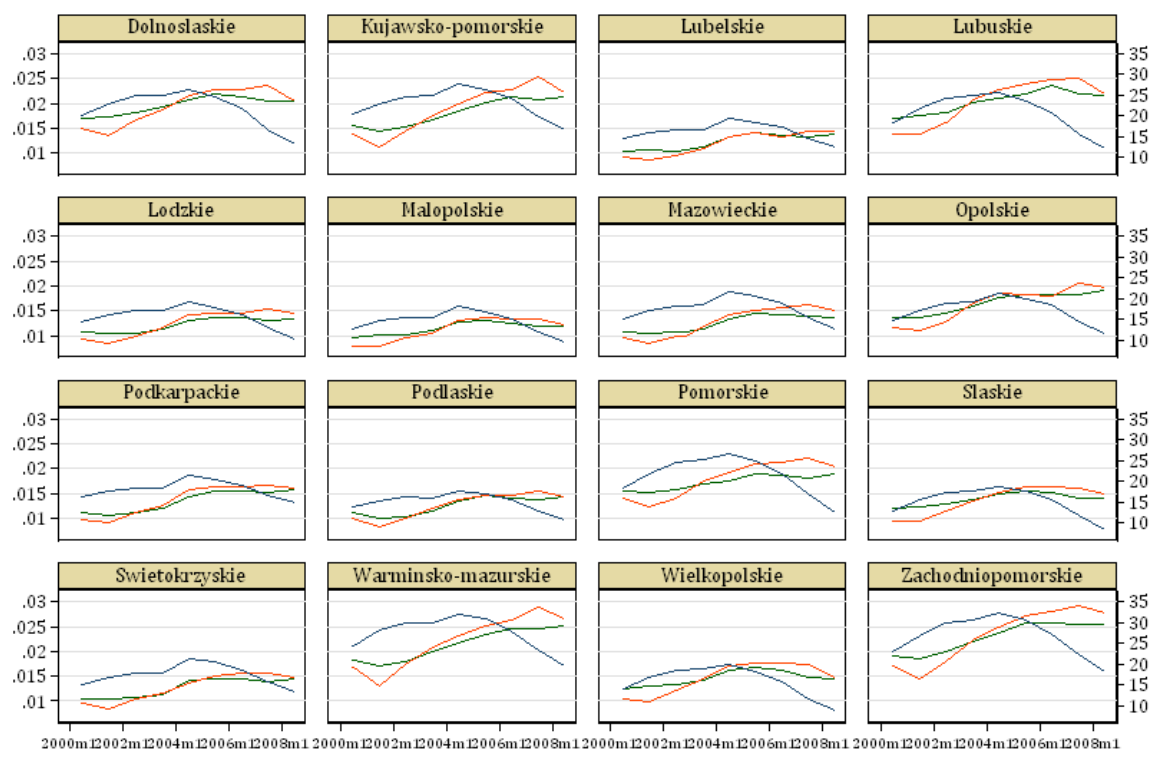

Mean INFLOWS

Mean OUTFLOWS

Mean unemployment rate

Figure 5. Point estimators (elasticities) by the decimal groups

Panel (a)




Panel (b)

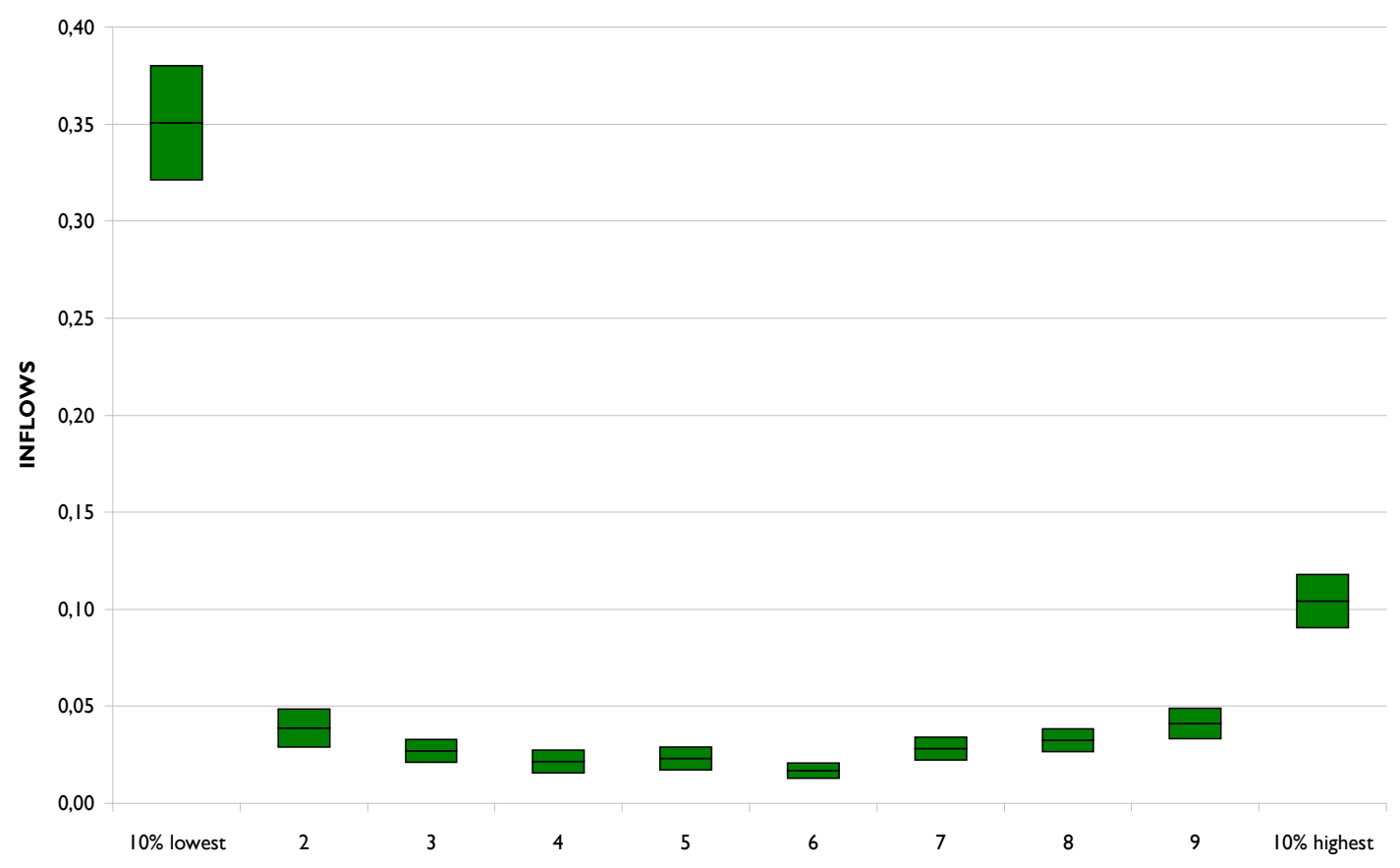

Panel (c)

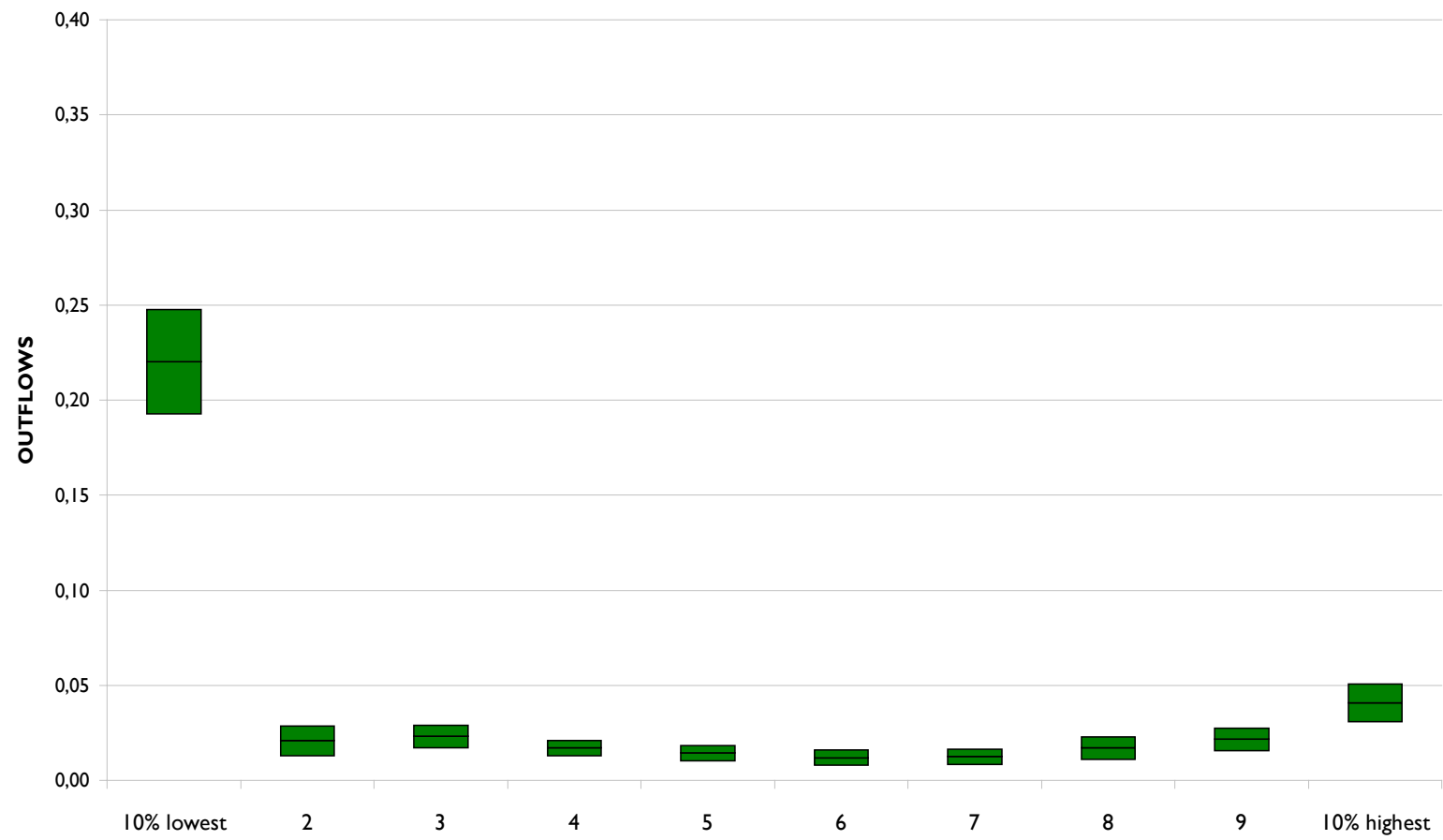

Note: Point estimators were obtained for decimal groups in separate estimations for each group. The values are obtained from estimation like the one presented in column 2 of Table 4.

Source: Own elaboration. 
Figure 6. Scatter plot of turnover, inflows and outflows in 2000 against the unemployment rate in 2008 by poviats

Panel (a)



Panel (b)

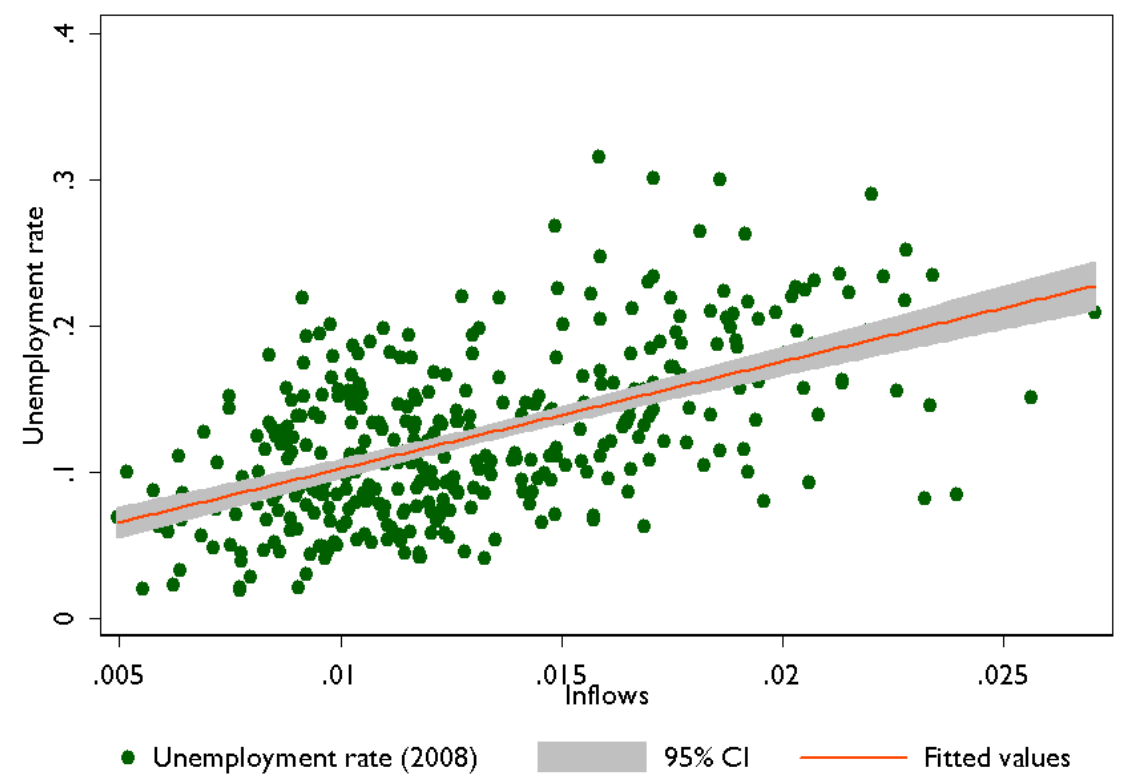


Panel (c)

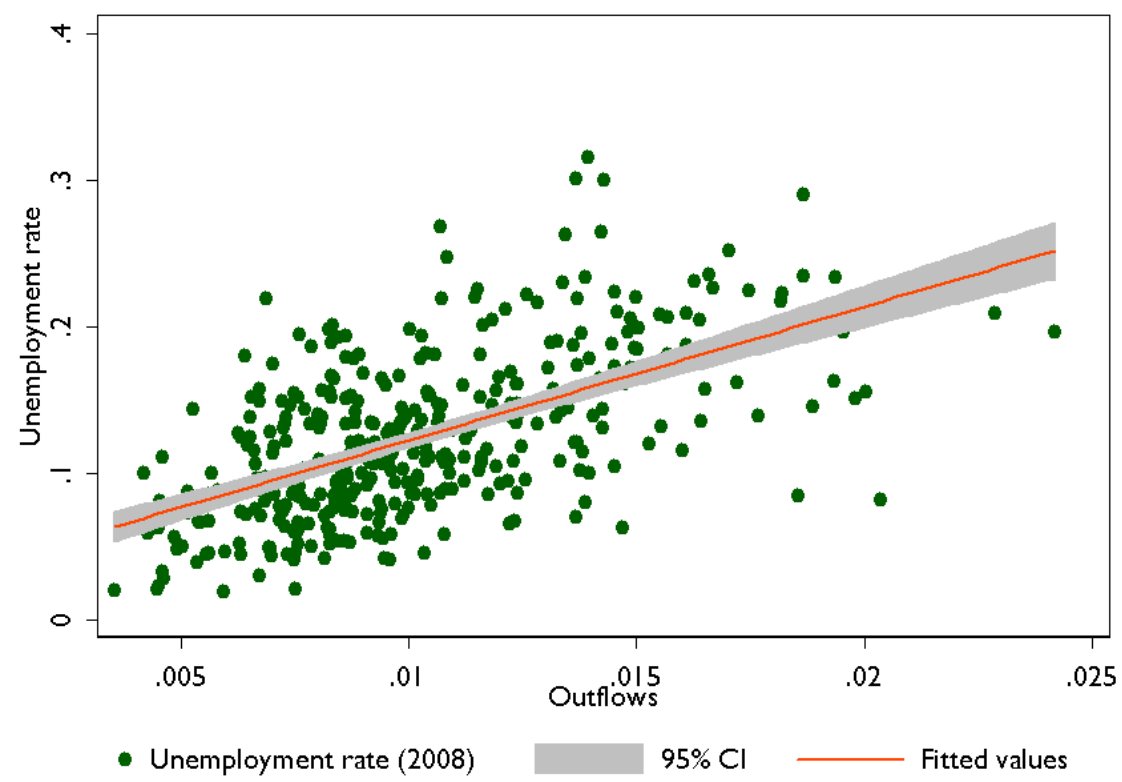

Note: Figure displays the scatter plots of the unemployment rate in 2008 on the vertical axis against the turnover (panel a), inflows (panel b) and outflows (panel c) in 2000; annual averages.

Figure 7. Turnover as a share of labour force (averaged over 2001-2008)

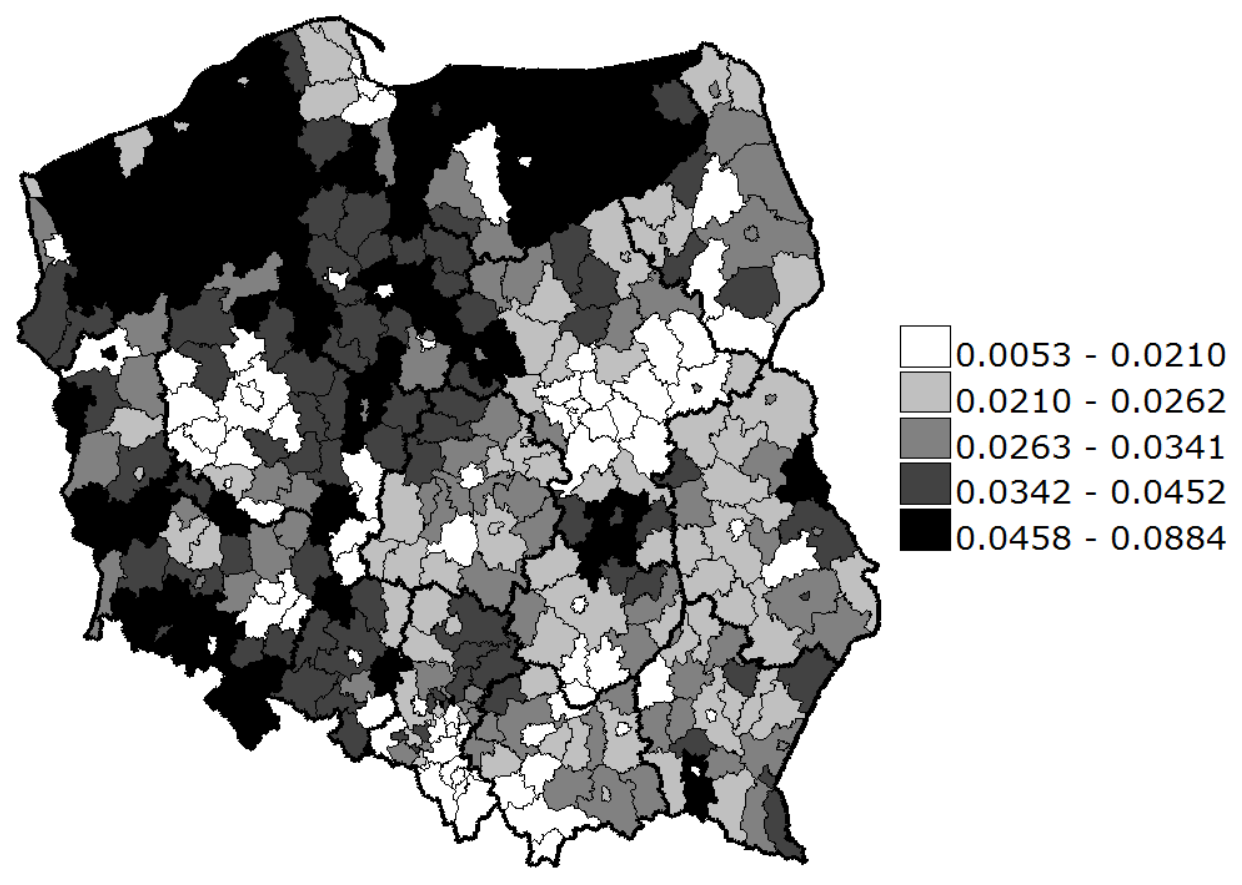






Figure 9. Ratio of institutional flows over market driven flows



